\title{
COMMENTS
}

\section{ASSUMING JURISDICTION ARGUENDO: THE RATIONALE AND LIMITS OF HYPOTHETICAL JURISDICTION}

Early in April of 1978, the Court of Appeals for the District of Columbia announced its opinion in the case of Edwards $v$. Carter. ${ }^{1}$ Without deciding several threshold challenges to its jurisdiction, the court rendered judgment on the merits of a novel constitutional question of importance to the future of the Panama Canal Treaty ${ }^{2}$ then pending in the Senate.

The treaty, as presented to the Senate by President Carter, contained provisions for transferring substantial amounts of United States property in the Canal Zone to Panama. ${ }^{3}$ This proposed property transfer raised the issue, hotly debated in the Senate and decided by the court, whether the President's power to make treaties with the advice and consent of the Senate ${ }^{4}$ includes the power to dispose of United States-owned property, or whether the disposal power is exclusively vested in the entire Congress by article IV of the Constitution. ${ }^{5}$

The plaintiffs, Representative Mickey Edwards and fifty-nine of his colleagues in the House of Representatives, sued President Carter, requesting a declaratory judgment that only the entire Congress could dispose of the U.S.-owned Canal Zone property, and that it thus could not be transferred to Panama through the exercise of the treaty power alone. The district court ruled that the congressmen lacked standing, and dismissed the complaint for lack of jurisdiction. ${ }^{6}$ On appeal, the President urged affirmance on the standing ground, arguing additionally that the issue was not yet ripe and that the case presented a nonjusticiable political question. Characterizing these questions as "substantial and complex," the court

1580 F.2d 1055 (D.C. Cir.), cert. denied, 436 U.S. 907 (1978).

2 Panama Canal Treaty, Sept. 7, 1977, United States-Panama, S. Exrc. Doc. N, 95th Cong., 1st Sess. (1977) (to enter into force Oct. 1, 1979). The full text of the treaty is set forth in an appendix to Edwards, 580 F.2d at 1104-21.

3 The property transfer is set out in article XIII of the treaty, reprinted in 580 F.2d at 1114-15.

4 U.S. CoNsT. art. II, $\$ 2$, cl. 2.

$5 I d$. art. IV, $\S 3$, cl. 2.

${ }^{6}$ Edwards v. Carter, 445 F. Supp. 1279, 1286 (D.D.C.), affd, 580 F.2d 1055 (D.C. Cir.), cert. denied, 436 U.S. 907 (1978). 
of appeals nevertheless found it unnecessary to address them ${ }^{7}$ and proceeded directly to the merits, dismissing the complaint for failure to state a claim upon which relief could be granted. ${ }^{3}$

As support for this unusual procedure, the court relied upon the authority of an increasing number of cases in which federal courts, confronted with difficult and far-reaching jurisdictional challenges, have assumed jurisdiction arguendo and proceeded to deny relief on the merits.

This practice of assuming jurisdiction arguendo, here dubbed "hypothetical jurisdiction," has developed for the most part without examination. The Supreme Court case most often cited as precedent, United States $v$. Augenblick, ${ }^{9}$ offers not a single word of analysis or justification, and little more has been forthcoming in more recent cases..$^{10}$ As a result, the policy underlying hypothetical jurisdiction has not been articulated and the proper limits of its exercise remain unexplored. The potential for serious abuse, which this Comment maintains was realized in the conduct of the Edwards v. Carter court, ${ }^{11}$ necessitates such an inquiry.

This Comment contends that the principled exercise of hypothetical jurisdiction can avoid unnecessary consideration of constitutional questions, conserve judicial resources, and aid in the administration of justice. Part I discusses the traditional policies of federal jurisdiction militating against hypothetical jurisdiction, and pays particular attention to jurisprudential considerations that have undercut the absolute nature of traditional jurisdictional rules. Part II sets forth the policy considerations justifying judicial power to exercise hypothetical jurisdiction. Part III sifts through the developing case law of hypothetical jurisdiction, attempting in the process to filter out guidelines for its discretionary use. In Part IV, $E d w a r d s v$. Carter is reexamined in light of the guidelines for hypothetical jurisdiction developed in the preceeding sections.

\section{The Jurisdictional Axiom}

The thesis of hypothetical jurisdiction-that a federal court may render a valid judgment on the merits while expressly

7580 F.2d at $1056-57$.

8 Id. 1064 .

9393 U.S. 348 (1969).

10 See, e.g., Norton v. Mathews, 427 U.S. 532 (1975); Secretary of the Navy v. Avrech, 418 U.S. 676 (1974); Adams v. Vance, 570 F.2d 950 (D.C. Cir. 1978); Southern Pac. Transp. Co. v. Usery, 539 F.2d 386 (5th Cir. 1976), cert. denied, 434 U.S. 874 (1977).

11 See test accompanying notes 197-217 infra. 
avoiding jurisdictional challenges to its power to hear the caseseems illogical. It appears to contradict the traditional principle that courts are powerless to act without jurisdiction over the subject matter, and that any order or judgment issued by a court without such jurisdiction is void and unenforceable. ${ }^{12}$ This axiom of jurisdiction, ${ }^{13}$ which to legal ears has the ring of analytic truth, nevertheless reflects a choice, supported and delimited by considerations of policy. ${ }^{14}$ In order to discover whether an exception for hypothetical jurisdiction can be tolerated, it is first necessary to take a closer look at the origins, justifications, and contours of this jurisdictional axiom.

Unlike jurisdiction over the person, which may be waived, ${ }^{15}$ jurisdiction over the subject matter may not, and can be challenged at any time. ${ }^{16}$ If any federal court perceives a problem of subject matter jurisdiction at any time prior to final judgment, it must raise the issue on its own motion, even though the parties do not wish to contest the issue, and must dismiss the action if jurisdiction is found lacking. ${ }^{17}$ If the court reaches the merits of a dispute without expressly addressing subject matter jurisdiction, a finding of jurisdiction is implied. ${ }^{18}$ Likewise, lack of standing, ${ }^{19}$ ripeness, ${ }^{20}$

12 See, e.g., American Fire \& Cas. Co. v. Finn, 341 U.S. 6 (1951); United States v. United States Fidelity \& Guar. Co., 309 U.S. 506, 514 (1940); In re Sawyer, 124 U.S. 200, 220-22 (1888); Ex parte McCardle, 74 U.S. (7 Wall.) 506, 514 (1869); Rose v. Himely, 8 U.S. (4 Cranch) 240, 268-69 (1808); The Marshalsea, 77 Eng. Rep. 1027 (K.B. 1612); Restatement (SECOND) of Conflict of Laws $\$ 92$, Comment i (1972).

13 "Axiom of jurisdiction" or "jurisdictional axiom" is used in this Comment as an umbrella term for a number of rules and doctrines, differentiated in the following text, all of which have as their common source the notion that subject matter jurisdiction is a necessary condition of judicial power. Although the jurisdictional axiom is not confined to the federal court system, this Comment will consider it only in that context.

No attempt will be made to define "subject matter jurisdiction," except to distinguish it from jurisdiction over the person. See generally Dobbs, The Decline of Jurisdiction by Consent, 40 N.C. L. Rev. 49, 49 n.1 (1961) [hereinafter cited as Consent].

14 United States v. United States Fidelity \& Guar. Co., 309 U.S. 506, 514 (1940); Consent, supra note 13, at 52.

15 Petrowski v. Hawkeye-Security Ins. Co., 350 U.S. 495 (1956); FED. R. Grv. P. 12(h)( 1 ; ; C. Wriget, A. Miller, \& E. Cooper, 5 Federal Practice and Procedure \$1391 (1975) [hereinafter cited as Wright \& MALLER].

16 American Fire \& Cas. Co. v. Finn, 341 U.S. 6, 17-18 (1951); Mitchell v. Maurer, 293 U.S. 237, 244 (1934); Capron v. Van Noorden, 6 U.S. (2 Cranch) 126, 127 (1804); FED. R. Crv. P. 12(h)(3); 5 WRTGHT \& MIILER, supra note 15, at $\$ 1393$.

17 Liberty Mut. Ins. Co. v. Wetzel, 424 U.S. 737, 740 (1976); Mansfield, C. \& L.M. Ry. v. Swan, 111 U.S. 379, 382-89 (1884).

18 Stoll v. Gottlieb, 305 U.S. 165, 171-72 (1938).

19 Juidice v. Vail, 430 U.S. 327, 331 (1977).

20 Regional Rail Reorganization Act Cases, 419 U.S. 102, 138 (1974). 
and mootness ${ }^{21}$ are all issues that the court has a duty to decide. ${ }^{22}$ Similarly, whether a case presents a non-justiciable political question, although not a jurisdictional question in the same sense as subject matter and case or controversy requirements, ${ }^{23}$ is nevertheless a threshold inquiry that the court has an obligation to undertake. ${ }^{24}$

"First principles" often lose their luster when examined in the light of their history, which is frequently filled with accident and devoid of logic. Professor Dobbs has traced the development of the jurisdictional axiom to the English royal courts, which used the concept of coram non judice to assert a national jurisdiction at the expense of traditional local tribunals. Royal courts voided the judgments of ecclesiastical or "inferior" courts for want of jurisdiction, thereby creating a process of review that permitted "superior" royal courts to correct injustices. ${ }^{25}$ Exactly why jurisdiction over the subject matter and not jurisdiction over the person became the peculiar test of a court's authority is unclear, ${ }^{26}$ but it is thought that its plasticity as a concept, its appearance on the face of the record, and its effectiveness as a counterweight to the largely territorial limits on the jurisdiction of English courts account for its eventual prominence. ${ }^{27}$ Although articulated by Coke early in the seventeenth century, subject matter jurisdiction as a necessary condition of a valid judgment did not gain wide acceptance until the next century, and was only elevated to black-letter law by the late Victorian text-writers. ${ }^{28}$

\section{A. The Rule Against Waiver}

The jurisdictional axiom's functional origins and its close ties to the idiosyncratic historical development of the English court system naturally raise the question of its continuing value in the modern judicial environment. Criticism has been focused on that

21 Kremens v. Bartley, 431 U.S. 119 (1977); North Carolina v. Rice, 404 U.S. 244,246 (1971).

22 See Pugh, The Federal Declaratory Remedy: Jurisdiction and Related Problems, 6 VAND. L. Rev. 79, 84-96 (1952).

23 Baker v. Carr, 369 U.S. 186, 198-99 (1962). See generally Scharpf, Judicial Review and the Political Question: A Functional Analysis, 75 YALE L.J. 517 (1966).

24 Adams v. Vance, 570 F.2d 950, 954 n.7 (D.C. Cir. 1978).

25 See Consent, supra note 13, at 54-66; Note, Filling the Void: Judicial Power and Jurisdictional Attacks on Judgments, 87 Yare L.J. 164, 165-71 (1977) [hereinafter cited as Filling the Void].

26 Gavit, Jurisdiction of Courts, 11 IND. L.J. 524, 546-47 (1936).

27 Consent, supra note 13, at 75-78.

$28 I d$. 
aspect of the axiom that prohibits waiver of subject matter jurisdiction, allowing jurisdictional challenges to be raised at any time prior to final judgment, ${ }^{29}$ on the grounds that it encourages unsound judicial administration ${ }^{30}$ and violates principles of fundamental fairness. ${ }^{31}$

If, as critics of the rule against waiver have proposed, the opportunity to raise the issue of subject matter jurisdiction should be foreclosed to the parties and to the court at some point prior to final judgment on the merits, the policies underlying the present rule must be addressed. The first of these policies is avoidance of the danger that a court will be compelled to render judgment in a case lying beyond the article III judicial power of the federal courts. $^{32}$ Second, even if the case is within article III bounds, exercising jurisdiction in excess of specific congressional grants may violate principles of federalism by encroaching on state court powers. Third, the weeding function now performed by subject matter jurisdictional requirements may be jeopardized; ${ }^{33}$ although the current rule may encourage temporary concealment of jurisdic-

29 I Moore's Federal Practice f 0.60(4), at 631-32 (2d ed. 1948); ALI Study of the Divition of JuRusdiction Between State and Federal Courts $\$ 1386$ \& 366-74 (1969) [hereinafter cited as ALI STudy]; Dobbs, Beyond Bootstrap: Foreclosing the Issue of Subject Matter Jurisdiction Before Final Judgment, 51 MinN. L. REv. 491 (1967) [hereinafter cited as Beyond Bootstrap]. Postjudgment application of the jurisdictional axiom has not been a problem for several decades because judgments issuing from courts lacking jurisdiction are res judicata. See text accompanying notes 50-58 infra.

30 The federal courts, it is true, are courts of limited jurisdiction. Jurisdiction represents the distribution of judicial power in our federal system as blueprinted by the Constitution and declared by Congress; and the federal courts ought therefore to be mindful that they stay within defined limits. These are broad working principles and ought not to be applied destructively.

1 Moore's Federax Practice $\llbracket 0.60$ (4), at 631 (2d ed. 1948).

31 American Fire \& Cas. Co. v. Finn, 341 U.S. 6 (1951), is the classic example. Defendant succeeded in removing the case to the federal district court, which found for plaintiff. Defendant then won on appeal on the ground that the removal was improper because the district court lacked jurisdiction. See also Kroger v. Owen Equip. \& Erection Co., 558 F.2d 417 (8th Cir. 1977), rev'd, 437 U.S. 365 (1978). But see Di Frischia v. New York Cent. R.R., 279 F.2d 141 (3d Cir. 1960); Klee v. Pittsburgh \& W.Va. Ry., 22 F.R.D. 252 (W.D. Pa. 1958), noted in Stephens, Estoppel to Deny Federal Jurisdiction-Klee and Di Frischia Break Ground, 68 Dick. L. Rev. 39 (1963).

32 U.S. Const. art. III, $\$ 2$ ("The judicial Power shall extend to all Cases, in Law and Equity, arising under this Constitution, the Laws of the United States, and Treaties made, or which shall be made, under their Authority . . . .").

33 " If this [jurisdiction by mere consent of the parties] were once conceded, the Federal courts would become the common resort of persons who have no right, either under the Constitution or the laws of the United States, to litigate in those courts." American Fire \& Cas. Co. v. Finn, 341 U.S. 6, 18 n.17 (1951) (quoting People's Bank v. Calhoun, 102 U.S. 256, 260 (1880)). 
tional defects, not all cases fall into that category, and once a defect becomes apparent, the court is freed of further expenditures of judicial energies. Fourth, the rule as it exists encourages fairness insofar as a party unable to launch a timely attack upon the court's jurisdiction is given a second chance.

The American Law Institute has placed its weight behind a proposal to legislatively curtail this jurisdictional fetish ${ }^{34}$ by prohibiting the consideration of subject matter jurisdiction once trial has commenced or other disposition on the merits has occurred in the district court. ${ }^{35}$ Exceptions would prevent collusion, unfairness to the party unable to raise timely objections, and the foreclosure of objections to defects that rise to a constitutional level. ${ }^{36}$

This last exception for constitutional defects was included as a safety valve at the insistence of the Institute, despite the Reporters' view that it was unnecessary.37 In the Reporters' opinion article III is flexible enough to justify restricting objections to jurisdictional defects in order to further sound judicial administration: "It is necessary and proper to exercise of Article III power that procedures be devised to require issues of jurisdiction to be timely raised, and to prevent their use to take unfair advantage of opposing parties or to impede the administration of justice." 38 Whether or not the Reporters' assessment of article III's flexibility is accurate, the inclusion of the exception for constitutional defects obviates concern over possible judgments beyond the court's article III power.

Neither the proposal nor the commentary explicitly addresses the potential for encroachment on state judicial power, an omission that seems odd in view of attempts to explain the harshness of the existing rule as arising from vigilant federalism. ${ }^{39}$ The ALI proposal, however, does contain adequate safeguards against significant alteration of the federal-state balance. First, it is possible that the judiciary would extend the exception for jurisdictional defects of constitutional stature to include jurisdictional flaws based on dis-

34 Professor Moore uses the term "fetish" to describe the rule that subject matter jurisdiction can be raised at any time. 1 Moore's Federax Practice $\uparrow 0.60(4)$, at 624-32 ( $2 \mathrm{~d}$ ed. 1948). The fetish is narrower than the jurisdictional axiom. See note 13 \& text accompanying note 12 supra.

35 ALI STODY, supra note 29 , at $\$ 1386$.

$36 I d . \$ 1386(\mathrm{a})(2),(3),(5)$.

37 Id. $368-69,373$.

38 Id. 368.

39 See, e.g., 13 Wrught \& MHr.ER, supra note 15 , at $\$ 3522$. 
cretionary principles in support of state power. ${ }^{40}$ Even if such extension were not to occur, other provisions of the proposal would serve to protect against federal intrusions into state power by ensuring that jurisdictional missteps were rare. The parties or the court would remain able to raise the issue of subject matter jurisdiction at any time prior to trial or disposition on the merits. ${ }^{41} \mathrm{~A}$ timely objection in the trial court could be raised again on appeal, ${ }^{42}$ and collusion between opposing parties would be grounds for dismissal at any time prior to final judgment. ${ }^{43}$ Resolution of jurisdictional problems could be postponed pending further clarification of relevant facts or pending appellate review, ${ }^{44}$ and, finally, a party unable to assert a timely objection would not be foreclosed from raising it later. ${ }^{45}$ It is doubtful that the prospect of occasional cases reaching judgment with known jurisdictional defects is a sufficiently serious impediment to healthy federalism to justify the excesses invited by the existing rule.

The ALI proposal, although aimed at sound judicial administration, takes inadequate account of the weeding function currently performed by the subject matter fetish. The principle that jurisdictional matters should ordinarily be taken care of at the outset of litigation is unquestionably valid. ${ }^{46}$ From the administrative point of view, however, there is no reason that this wisdom must be petrified in a prohibition. The ALI proposal would require that cases in which lack of jurisdiction became apparent but no exception applied be processed through to completion, no matter what the cost in judicial resources. A better alternative would vest the courts with discretion to dismiss. Used in a principled manner, such discretion would discourage dilatory tactics as effectively as would a flat prohibition.

With respect to fairness to the parties, the ALI proposal greatly improves upon current practice. No longer would a defendant be encouraged to conceal a jurisdictional defect until the statute of limitations had run and then render himself immune to the suit by a tardy attack on the court's jurisdiction. The sole fairness ad-

40 The abstention doctrine is an example of one such discretionary protection, as opposed to a constitutional requirement such as the need for a federal cause of action. See generally Field, Abstention in Constitutional Cases: The Scope of the Pullman Abstention Doctrine, 122 U. PA. L. Rev. 1071 (1974).

41 ALI STUDY, supra note 29, at $\$ 1386$ (a).

42 Id. $\$ 1386$ (a) (4).

43 Id. $\$ 1386$ (a)(3).

44 Id. $\$ 1386$ (a)(1).

$45 I d$. $\$ 1386(\mathrm{a})(2)$.

46 Z. Chafee, Some Problems of EquTty 316-21 (1950). 
vantage of the existing rule would be preserved by the proposal's exemption, previously mentioned, for situations in which the party challenging jurisdiction was unable to do so in a timely fashion. ${ }^{47}$

To one dogged critic of traditionally sanctimonious jurisdictional thinking, the ALI proposal errs by being too conservative, in allowing jurisdictional defects to be raised at any time before a case comes to trial.48 Although the selection of this cutoff point, rather than an earlier one, may conceivably work unfairness to a party engaged in lengthy pre-trial proceedings, the ALI proposal wisely removes the greatest incentive and the most egregious harm by tolling the statute of limitations until thirty days after dismissal of the original action on jurisdictional grounds. ${ }^{49}$ No system of procedures has yet been invented that renders unfairness impossible, and whatever the ALI proposal lacks in that regard is arguably outweighed by the strong interest in policing the limits of federal court jurisdiction.

Thus, none of the four policies identified as supporting the current rule are sufficiently weighty to justify its rigidity. On the contrary, principles of sound judicial administration and fairness point to a modification that would allow federal courts a limited discretion to ignore jurisdictional errors not raised in timely fashion. Such a result should not be surprising in light of the established policy of overlooking jurisdictional infirmities once final judgment has been rendered. That policy will be discussed next, in the context of collateral attacks on jurisdictionally defective judgments.

\section{B. Res Judicata and the Bootstrap Doctrine}

At common law, judgments rendered by a court lacking jurisdiction over the subject matter were void and vulnerable to collateral attack. The modern view is largely opposite: as a rule, such judgments will be enforced as valid, ${ }^{50}$ no matter whether the court

47 ALI STUDx, supra note 29 , at $\$ 1386$ (a)(2).

48 Beyond Bootstrap, supra note 29 , at 525-28.

49 ALI STODY, supra note 29 , at $\$ 1386$ (b), (c).

50 See generally Boskey \& Braucher, Jurisdiction and Collateral Attack, October Term, 1939, 40 Colun. I. REv. 1006 (1940). Immunity from collateral attack for subject matter jurisdictional defects had been conferred on federal court judgments as early as Des Moines Nav. \& R.R. Co. v. Iowa Homestead Co., 123 U.S. 552, 557 (1887). The traditional doctrine was not firmly displaced, however, until the decisions in Stoll v. Gottlieb, 305 U.S. 165 (1938), and Chicot County Drainage Dist. v. Baxter State Bank, 308 U.S. 371 (1940). Boskey and Braucher interpret Stoll and Chicot County as suggesting that, with the exception of cases presenting considerations which outweigh the policy against collateral attack, see, e.g., Kalb v. Feuerstein, 308 U.S. 433 (1940), "no special sanctity should attach to jurisdictional limitations, deriving often from judicial convenience or mere historical accident." Boskey \& Braucher, supra, at 1010. 
merely overstepped the bounds of a valid statutory grant of jurisdiction, whether the jurisdictional statute is found unconstitutional, ${ }^{51}$ or whether the court violated article III limits on federal jurisdiction. ${ }^{52}$

The rule that jurisdictional determinations are res judicata is founded on the overriding interest in the finality of judgments. The policy of requiring an end to litigation is now recognized as sufficiently strong to foreclose recourse to the argument that jurisdictional matters should be treated differently from substantive issues because jurisdiction involves the court's "power" over a case. ${ }^{53}$ Significantly, however, finality is not an absolute. In United States v. United States Fidelity o Guaranty Co., ${ }^{54}$ a judgment based on an improper waiver of sovereign immunity was held not to be res judicata because the policy interests behind the sovereign immunity doctrine were thought to outweigh the interest in repose. ${ }^{55}$ In a similar vein, the Restatement of Judgments lists a group of factors to be weighed by a court when faced with a collateral attack on a jurisdictionally defective judgment. ${ }^{56}$

Although the policy of finality is clear, the attempt to reconcile it with the axiom that judgments issuing from a court lacking jurisdiction are void has created doctrinal difficulties. The prevailing fiction, known as the "bootstrap" doctrine, ${ }^{57}$ reasons that a court has jurisdiction to determine its own jurisdiction, and, whether that determination is correct or not, it is binding unless overturned on appeal. ${ }^{58}$

The bootstrap doctrine has proved useful in contexts other than collateral attack. In United States $v$. United Mine Workers, ${ }^{59}$ the district court issued an ex parte temporary restraining order against a proposed strike in mines that were under the control of the federal government. Rather than appeal the order, the union chose to ignore it, apparently in the reasonable belief that the Norris-

51 Chicot County Drainage Dist. v. Baxter State Bank, 308 U.S. 371 (1940).

52 Swift \& Co. v. United States, 276 U.S. 311, 325-26 (1928) (no case or controversy); Des Moines Nav. \& R.R. Co. v. Iowa Homestead Co., 123 U.S. 552 (1887) (lack of diversity). See Z. ChafeE, supra note 46, at 370-71.

53 See Treinies v. Sunshine Mining Co., 308 U.S. 66, 78 (1939).

54309 U.S. 506 (1940).

55 Id. 514.

66 Restatement of JUDGMENTS $\$ 10$ (1942).

57 The term was apparently coined in Note, Res Judicata and Jurisdiction: The Bootstrap Doctrine, 53 HARv. L. Rev. 652 (1940).

58 See Beyond Bootstrap, supra note 29, at 496; Dobbs, The Validation of Void Judgments: The Bootstrap Principle, 53 VA. L. Rev. 1003, 1241 (1967). But see Z. ChafeE, supra note 46 , at $319 \mathrm{n} .42$.

59330 U.S. 258 (1947). 
LaGuardia Act of $1932{ }^{60}$ deprived the court of jurisdiction to enjoin a labor dispute. Contempt citations ensued and were upheld by the Supreme Court. The majority opinion argued that the district court did have jurisdiction despite the Norris-LaGuardia Act, and alternatively, even if it did not have jurisdiction, the order was valid and deserving of respect because a court has the power to determine its own jurisdiction and to issue interim orders to preserve the status quo.61 The latter branch of the Court's holding overturned established precedents that no duty existed to obey an order issued by a court lacking jurisdiction. ${ }^{62}$

United Mine Workers thus stands for the proposition that, when confronted with novel and substantial jurisdictional questions, a federal court has the power to issue temporary relief to preserve the status quo while inquiring into its own jurisdiction. ${ }^{63}$ The labor context of the case, however, suggests a broader reading. It has long been recognized that ex parte restraining orders against strikes, although "temporary" in name, in fact permanently dispose of the merits by awarding the complaining party the desired relief and mooting the dispute. ${ }^{64}$ This phenomenon was a prominent factor in the passage of the Norris-LaGuardia Act, which deprived federal courts of jurisdiction to issue labor injunctions. ${ }^{65}$ Given this history, it is somewhat coy to view United Mine Workers as limiting bootstrap jurisdiction to orders maintaining the status quo. In effect, the district court resolved the merits of the dispute without first having established its jurisdiction, and this procedure was validated by the Supreme Court. If this reading of the case is correct, then bootstrap jurisdiction arguably allows a court not merely to preserve the status quo, but effectively to issue substantive rulings as well. ${ }^{60}$

6029 U.S.C. $\$ \$ 101-115$ (1976).

61330 U.S. at $289-95$.

62 In re Sawyer, 124 U.S. 200 (1888); Ex parte Fisk, 113 U.S. 713 (1885). But see United States v. Shipp, 203 U.S. 563 (1906). See generally Cox, The Void Order and the Duty to Obey, 16 U. CH. L. Rev. 86 (1948); Rendleman, More on Void Orders, 7 GA. L. Rev. 246 (1973).

63 The precedential weight of that part of the opinion which held the order valid even if the district court lacked jurisdiction is open to question. Of the five justices who so held, three also held that in fact the district court did have jurisdiction; for them, the rest was dictum. Only two members of the Court, Justices Frankfurter and Jackson, firmly held that the district court's order was enforceable even though the court lacked jurisdiction to issue it. See Z. Crafee, supra note 46, at $365-67$.

64 F. Frankfurter \& N. Greene, The Labor Injunction 200-01 (1930).

65 See Z. Chafee, supra note 46 , at 373.

${ }^{66}$ See Giancana v. Johnson, 335 F.2d 372 (7th Cir. 1964); 13 Wrigrr \& MULER, supra note 15 , at $\$ 3537$. 
The opinion in United Mine Workers, to the extent that it offered any rationale, rested on grounds of necessity and the resulting judicial impotence if parties before the court were to be free to ignore its orders. ${ }^{67}$ Justice Frankfurter, concurring in the judgment, provided more forceful justification, prophesying not only reduced prestige of the courts, but also an end to "a government of laws and not of men" if the contempt findings were not enforced.68

These arguments of necessity do not explain how the courts and American society managed to survive the long period when the law held that lack of jurisdiction was a valid defense to a contempt charge. Moreover, the majority and Justice Frankfurter both specifically excepted situations in which the jurisdictional issues purportedly being considered by the court were frivolous, an indication that the perceived necessity was a relative one. ${ }^{69}$ Nor, in the majority's view, was the necessity so great as to require enforcement of civil, as opposed to criminal, contempt findings if the court lacked jurisdiction. ${ }^{70}$ What the Court paraded as necessity was in reality a redefined notion of what is mandated by principles of sound judicial administration. If policy indicates that respect for the judicial process requires finality for erroneous jurisdictional as well as substantive findings, there is no reason why orders of a court lacking jurisdiction cannot likewise be enforced, ${ }^{71}$ whether those orders are procedural or substantive in nature. Thus stripped of rhetoric, United Mine Workers represents a balanced judgment that the policy underlying the axiom of jurisdiction does not outweigh the advantages to judicial administration of a duty to obey "void" orders.

This brief survey demonstrates that "the mistaken notion that there is something peculiarly brittle and theological about jurisdictional concepts" 72 has been significantly eroded by modern

67330 U.S. at $289-95$.

68 Id. 307 (Frankfurter, J., concurring in the judgment).

69 Id. $293,310$.

70 Id. $294-95$.

71 But just as in the field of res judicata the public interest in finality of litigation led the courts to modify, and in large measure to abandon, the distinction between jurisdictional infirmities and mere error, so . . . [with "void" orders] the general public interest in vindicating the authority of the courts and in encouraging the orderly conduct of litigation may well justify judicial reconsideration of the same distinction.

Cox, supra note 62 , at 115 .

72 Gavit, supra note 26 , at 543 . 
trends. Today, with few exceptions, ${ }^{73}$ a judgment is res judicata, even if the court that rendered it lacked jurisdiction over the subject matter. Interim orders are enforceable in certain circumstances despite jurisdictional infirmities. Furthermore, a cogent attack has been mounted on the rule that lack of subject matter jurisdiction may be raised at any time prior to final judgment and must be noticed by the court. In each of these contexts, the requirements of sound judicial administration are thought to outweigh the substance of the inherited dogma that actions by a court taken beyond its jurisdiction are void. Although these developments have created doctrinal difficulties as yet unresolved, it seems safe to say that the validity of additional modifications depends upon the relative weight of the policies supporting them.

Before proceeding to an examination of the policies favoring the use of hypothetical jurisdiction, the reduced role of the jurisdictional axiom will be further explored by outlining related developments in ancillary and pendent jurisdiction.

\section{Ancillary and Pendent Jurisdiction}

Federal subject matter jurisdiction has long been considered flexible enough to encompass claims of parties and proceedings supplemental or ancillary to the main action ${ }^{74}$ and dependent nonfederal claims involving the original parties. ${ }^{75}$ In both situations the federal court asserts jurisdiction over claims that, but for their intimate relation to subject matter properly before the court, would lie outside the article III sphere of power. The modern trend has been to expand the closely related doctrines of ancillary and pendent jurisdiction to further the sound administration of the federal judicial system. ${ }^{76}$

As conceived, ancillary jurisdiction was considered necessary to the ability of a federal court to decide the case before it. ${ }^{77}$ In Moore v. New York Cotton Exchange, ${ }^{78}$ this rationale was expanded. In that case, plaintiff sued on a federal antitrust statute; defendant's

${ }^{73}$ See Durfee v. Duke, 375 U.S. 106, 114 n.12 (1963); In re Green, 369 U.S. 689 (1962); United States v. United States Fidelity \& Guar. Co., 309 U.S. 506 (1940).

74 Freeman v. Howe, 65 U.S. (24 How.) 450 (1860).

75 Osborn v. Bank of the United States, 22 U.S. (9 Wheat.) 738 (1824).

76 See Baker, Toward a Relaxed View of Federal Ancillary and Pendent Jurisdiction, 33 U. PItT. L. Rev. 759 (1972).

77 Freeman v. Howe, 65 U.S. (24 How.) 450 (1860); see 13 WrighT \& MrIIER, supra note 15 , at $\$ 3523$.

78270 U.S. 593 (1926). 
compulsory counterclaim requested an injunction. The Court rejected the plaintiff's antitrust argument and could have dismissed the counterclaim, as there was neither diversity between the parties nor any other independent basis for federal jurisdiction. The Court chose to grant the injunction, however, noting that dismissal would "rob ... of all serviceable meaning" the rule that counterclaims arising out of the same transaction must be pleaded. ${ }^{79}$ Thus, the case has been interpreted as making procedural convenience an adequate justification for extending federal judicial power beyond explicit congressional grants of jurisdiction under article III. ${ }^{80}$

The Supreme Court has not delimited the outer bounds of ancillary jurisdiction; however, United Mine Workers $v$. Gibbs, ${ }^{81}$ a case addressing pendent jurisdictional issues, has been perceived as expanding the scope of both doctrines. ${ }^{82}$ To the Gibbs Court, pendent jurisdiction, traditionally limited to joinder of state and federal claims involving the same parties, was grounded in a broadened constitutional definition of "case." State and federal claims constitute a single case under article III if they "derive from a common nucleus of operative fact" and if a plaintiff would "ordinarily be expected to try them" in one proceeding. ${ }^{83}$ Judicial power to take pendent jurisdiction was sharply distinguished from the exercise of that power, which is a matter for the court's discretion, to be governed by considerations of judicial economy, procedural convenience, and fairness to the parties. ${ }^{84}$

The Court did not attempt to justify the generous notion of a constitutional "case" it employed. Although the opinion duly paid lip service to the credo that adoption of the Federal Rules of Civil Procedure did not enlarge the jurisdiction of the federal courts, ${ }^{85}$ it is likely that the same considerations of judicial economy, fairness, and convenience embodied in the Rules were at play in expanding the constitutional definition of "case." 86 The Court's final standard for ascertaining judicial power to exercise pendent jurisdiction makes this conclusion nearly inescapable: "But if . . .

79 Id. 610. See Comment, Pendent and Ancillary Jurisdiction: Towards a Synthesis of Two Doctrines, 22 U.C.L.A. L. REv. 1263, 1267 (1975).

8013 WRIGHT \& MHLIER, supra note 15 , at $\$ 3523$; see Rosado v. Wyman, 397 U.S. $397,405,425$ (1970).

81383 U.S. 715 (1966).

82 See, e.g., Baker, supra note 76, at 763; Comment, supra note 79, at 1271.

83383 U.S. at 725 .

84 Id. 726.

85 Id. 725 n.13.

86 See generally Goldberg, The Influence of Procedural Rules on Federal Jurisdiction, 28 STAN. L. REv. 395 (1976). 
a plaintiff's claims are such that he would ordinarily be expected to try them all in one judicial proceeding, then ... there is power in federal courts to hear the whole." 87 After several decades of practice under the Rules, their spirit and policy necessarily permeate "ordinary expectations" of what claims would be tried in one court action. 88 It is therefore not unreasonable to conclude that the principles operative in extending federal jurisdiction to pendent claims are the same policy considerations that underlie ancillary jurisdiction and justify departure from the rule that, strictly speaking, a court has no power to decide a claim over which it has no independent jurisdictional power.

This is not to say that only considerations of efficiency and convenience shall determine a court's jurisdiction over the pendent claim. There must still be a "common nucleus of operative fact." Additionally, there may be statutory limits on the court's power to hear pendent claims. ${ }^{89}$ But neither of these strictures detracts from the thesis that, as with res judicata, the bootstrap doctrine, and ancillary jurisdiction, principles of sound judicial administration dilute the strength of the jurisdictional axiom and allow federal courts to entertain and decide claims over which they have no independent basis of jurisdiction.

\section{Hypothetical JuRISDiction: PoWer to AsSume JuRISDICTION ARGUENDo}

The fundamental question concerning hypothetical jurisdiction is one of judicial power: is it ever permissible for a federal court ${ }^{90}$ to assume jurisdiction arguendo and decide a case on its merits?

87383 U.S. at 725 . Federal power is also contingent on the substantiality of the federal issue. Id.

88 See Baker, supra note 76 , at 765 .

89 See Aldinger v. Howard, 427 U.S. 1 (1976). Accord, Owen Equip. \& Erection Co. v. Kroger, 437 U.S. 365 (1978). Although limited by the facts and the Court's careful limitation to the context of pendent parties, 427 U.S. at 17-18 n.12, the reasoning in Aldinger has been read by one commentator as implicitly extending to ordinary pendent jurisdiction as well. Comment, Aldinger v. Howard and Pendent Jurisdiction, 77 CoLum. L. REv. 127, 148 (1977).

90 In general, this Comment will ignore differences in the appropriateness of hypothetical jurisdiction as applied by district courts, courts of appeals, and the Supreme Court. Some of the policies set out below as supporting the validity of hypothetical jurisdiction, such as the policy of avoiding constitutional adjudication, will apply equally to all federal courts while others will not: the algebra of judicial economy will vary with the procedural posture and history of a case. It would be premature to attempt in this Comment to catalogue the innumerable possible permutations or to assess their significance for hypothetical jurisdiction. When appropriate, notice of relevant differences has been taken. See notes 113 \& 172 infra. 
This inquiry is preliminary to that focusing on the limits of the discretionary use of hypothetical jurisdiction, which is postponed until Part III. Here only the question of power is addressed. ${ }^{91}$

It should be noted that the discussion in Part I of various reforms in modern jurisdictional thinking has not preordained the result. Unlike the ALI proposal, ${ }^{92}$ hypothetical jurisdiction does not concern the timeliness of judisdictional challenges; it applies as well to the timely and fully litigated issue as to the tardy. Nor does it invoke the policy of repose that operates once final judgments have been rendered, ${ }^{93}$ or of respect for the courts that supports the duty to obey interim orders..$^{94}$ Moreover, unlike ancillary or pendent jurisdiction, ${ }^{95}$ with hypothetical jurisdiction there is no federal claim or action that creates an indisputable ground for federal jurisdiction. Although hypothetical jurisdiction may draw strength from these concepts by force of analogy, it must ultimately establish its own title to judicial power.

Judicial power to exercise hypothetical jurisdiction as used in this Comment is predicated upon two basic conditions. First, the jurisdictional point that is to be assumed arguendo must be difficult and far-reaching; no claim is made for power to avoid jurisdictional issues that are clearly frivolous or insubstantial, or even routine. ${ }^{96}$ Second, the question on the merits must be decided against the party

91 Questions of judicial power are only relevant, of course, if hypothetical jurisdiction actually occurs. An argument that it does not might build on the writings of Professor Chafee, who ventured the opinion, in the context of a discussion of equity jurisdiction, that much of what passes as juxisdictional actually concerns rules of right decision and does not go to the court's power. Z. CrafeE, supra note 46, at 296-363. His twin policies of the Bright Line and First Things First (respectively, the boundary between judicial power and nullity, and confining defects in power to issues able to be ascertained preliminarily), applied to hypothetical jurisdiction cases, might show that the questions bypassed were not at bottom questions of the court's power, but rather questions of how the court ought to exercise that powerthat is, questions on the merits. A court that chose to decide a case on its substantive merits, rather than confront the "jurisdictional merits," would simply be disposing of a case decidedly within its power on an alternative ground.

Although based on sound policy, this approach is rejected here because it does not comport with the courts' perceptions of the nature of the jurisdictional issues being avoided in hypothetical jurisdiction cases. See, e.g., Moor v. County of Alameda, 411 U.S. 693, 715 (1973); Adams v. Vance, 570 F.2d 950, 954 n.7 (D.C. Cir. 1978).

92 See text accompanying notes $34-48$ supra.

93 See text accompanying notes 50-58 supra.

94 See text accompanying notes 59-71 supra.

95 See text accompanying notes 74-89 supra.

96 No attempt is made to define "difficult" or "far-reaching," whose meaning can only be captured on a case-by-case basis. In other contexts, however, the existence of judicial power hangs upon the equally indefinable standard of substantiality. See United Mine Workers v. Gibbs, 383 U.S. 715, 725 (1966); United States v. United Mine Workers, 330 U.S. 258, 293 (1947). 
invoking the court's jurisdiction; if the complaining party is entitled to relief, then hypothetical jurisdiction is inappropriate. ${ }^{97}$ In the following analysis of judicial power, the satisfaction of these conditions will be assumed.

The major doctrinal barrier to the validity of hypothetical jurisdiction thus defined is the federal court's duty to inquire into its own and a lower court's jurisdiction and to dismiss the case if jurisdiction is found wanting: ${ }^{98}$ If this duty is absolute and admits of no exceptions, then hypothetical jurisdiction must fail.

One major purpose of imposing this duty on a court is obvious: it exists in order to ensure that federal courts do not stray beyond the limits on their power and fall into jurisdictional error. However, no sooner is this function of the duty identified than an exception can be made out. For when the gravity of jurisdictional error is slight, it is only reasonable that the duty to make jurisdictional findings is attenuated.

In a routine case in which the court's jurisdiction is a straightforward affair, the gravity of a jurisdictional error will be great: a court that takes jurisdiction over a case far beyond its legitimate reach is guilty of a serious violation of the limits on federal court jurisdiction. In the typical hypothetical jurisdiction case, however, the jurisdictional issue is a difficult one with far-reaching consequences. In a close case, in which the jurisdictional point could reasonably be resolved either way, the gravity of any potential jurisdictional error is significantly reduced, and the duty compelling the court to make a jurisdictional ruling appears in a new light. It no longer serves as a vehicle for policing the established boundaries of federal jurisdiction, but rather imposes a stiff regimen on the essentially creative process of testing and probing jurisdictional concepts at the frontiers of jurisdiction. In this context, the policy of avoiding jurisdictional error has diminished strength, and courts have quite reasonably taken competing policies into account. Avoidance of unnecessary constitutional adjudication, conservation of judicial energies, and considerations of sound judicial administration-policies developed more fully below ${ }^{99}$-may singly or in combination justify an exception to the court's duty to establish its jurisdiction before reaching the merits. ${ }^{100}$

97 The rationale for this condition is explored below. See text accompanying notes 129-38 infra.

88 See note 17 supra \& accompanying text.

99 See text accompanying notes 106-16 infra.

100 This functional approach to the scope of the court's duty to decide its jurisdiction finds support in Beyond Bootstrap, supra note 29, at 507-24. Professor 
A second justification for imposing an absolute duty on federal courts to establish their jurisdiction might be thought to derive from Chief Justice Marshall's famous statement that the Court has "no more right to decline the exercise of jurisdiction which is given, than to usurp that which is not given. The one or the other would be treason to the constitution." 101 A strict constitutional duty to decide a case once jurisdiction is given might be taken as requiring an equally strict antecedent duty to decide in every case whether jurisdiction does in fact exist.

The debate over the courts' duty to decide cases within their jurisdiction and the related virtues and vices of avoidance has been acute, ${ }^{102}$ but in assessing the relevance of that discussion to the validity of hypothetical jurisdiction it is important to note a crucial difference: whereas the debate over decision and avoidance focuses on the use of jurisdictional devices to avoid judgment on the merits, hypothetical jurisdiction authorizes judgment on the merits as a method of avoiding knotty jurisdictional matters.

To the extent that the judicial duty to decide a case on its merits derives from the duty to render substantive justice in the dispute between the parties, that duty is satisfied when the court enters judgment on the merits and avoids only the jurisdictional issue. Jurisdictional matters, more than substantive law, are peculiarly the province of the court, and the parties have only a derivative interest in them. Decisions on difficult jurisdictional questions are likely to have far-reaching consequences, as they are inevitably cast in

Dobbs' review of the case law widely thought of as supporting the traditional rule that subject matter jurisdictional issues can be raised at any time concludes that the actual rule contained in the holdings is a narrower one, limiting tardy jurisdictional attacks to cases in which lack of jurisdiction appears affirmatively from the record. Although his focus is on the tardy jurisdictional challenge, whereas hypothetical jurisdiction applies equally to jurisdictional contentions made in timely fashion, Dobbs' study corroborates the view that the court's duty originated in a concern over avoiding obvious jurisdictional error. Once the duty is so described, it can no longer be treated as absolute, and the door is open to consideration of competing values. See generally Wetmore v. Rymer, 169 U.S. 115 (1898); Hartog v. Memory, 116 U.S. 588 (1886).

Dobbs accordingly adopts a narrow interpretation of Federal Rule of Civil Procedure 12(h)(3), which provides: "Whenever it appears by suggestion of the parties or otherwise that the court lacks jurisdiction of the subject matter, the court shall dismiss the action." FED. R. Crv. P. 12(h)(3). In Dobbs' view, the federal rule, meant to codify the case law, goes no further than his revisionist reading of the cases. Beyond Bootstrap, supra note 29, at 519 .

101 Cohens v. Virginia, 19 U.S. ( 6 Wheat.) 264, 404 (1821).

102 See Bickel, The Supreme Court, 1960 Term-Foreword: The Passive Virtues, 75 Harv. L. REv. 40 (1961); Gunther, The Subtle Vices of the "Passive Virtues"A Comment on Principle and Expediency in Judicial Review, 64 Coutr. L. Rev. I (1964); Wechsler, Toward Neutral Principles of Constitutional Law, 73 HAnv. L. REv. 1 (1959). 
general terms and are seldom easily confined to specific factual situations. The continuing vitality of the jurisdictional fetish-the inability of the parties to waive lack of subject matter jurisdictionserves as a reminder that jurisdiction historically has been the special ward of the court, too highly valued to be entrusted to the parties.

Moreover, whatever interest the parties have in a finding of subject matter jurisdiction is extinguished by the court's dismissal on the merits. ${ }^{103}$ This was recognized by the Supreme Court in one hypothetical jurisdiction case when it expressed its unwillingness to decide the jurisdictional question by observing that "even the most diligent and zealous advocate could find his ardor somewhat dampened in arguing a jurisdictional issue where the decision on the merits is thus foreordained." 104

This assimilation of the rationale behind hypothetical jurisdiction to what Professor Bickel described as "passive virtues" 105 might be resisted on the ground that those avoidance techniques may only be justified by the imperative that courts perform in principled fashion their paramount duty to interpret substantive law. From this contrary perspective, hypothetical jurisdiction appears to be more an "active vice" than a "passive virtue": it permits courts to reach the merits of a case without making certain they have jurisdiction to do so. Such a practice cannot be validated by reference to the necessity that courts engage in principled adjudication of the merits.

Plainly, jurisdictional questions also have their "merits." The necessity for principled decision of complex jurisdictional matters is not inferior to that of substantive questions. It might even be argued that, insofar as they regulate access to the courts, jurisdictional decisions are in the long run of greater jurisprudential significance.

Thus, the notion that a court has an absolute duty affirmatively to establish its jurisdiction in every case neither can be located in the tradition based on the policy of avoiding jurisdictional error nor be derived from a constitutional duty to decide cases within the court's jurisdiction. Moreover, significant policies are furthered by acknowledging judicial power to assume jurisdiction arguendo. In

103 Hypothetical jurisdiction, by definition, only applies to cases in which the court finds against the party asserting jurisdiction. See text accompanying notes 129-38 infra and 97 supra. The party challenging jurisdiction would have no interest in raising jurisdictional issues once the case had been decided in his favor on the merits.

104 Secretary of the Navy v. Avrech, 418 U.S. 676, 678 (I974).

105 Bickel, supra note 102. 
any given case these policies may overlap, but they are sufficiently distinct to be articulated separately.

The first policy is the familiar one of avoiding constitutional rulings unless they are absolutely or "strictly" necessary to the disposition of the case. ${ }^{106}$ The "great gravity and delicacy" 107 of constitutional adjudication, which compels judicial restraint, is perhaps most acute when the constitutional question concerns self-imposed or congressionally mandated limits on federal court jurisdiction, for it is here that the role of the federal judiciary in the constitutional separation of powers is most directly confronted.

A second consideration is the conservation of judicial energies. The "explosion" of federal litigation has been much noted, and various reforms of a structural nature have been proposed. ${ }^{108}$ Procedural adjustments have also been required, and further changes will no doubt be essential in the foreseeable future. ${ }^{109}$ From an administrative standpoint, substantial savings in judicial resources can be achieved by allowing courts to skirt complex and timeconsuming jurisdictional arguments when the questions on the merits are more simply resolved. ${ }^{110}$ Those jurisdictional issues, and

106 Rescue Army v. Municipal Court, 331 U.S. 549 (1947); Ashwander v. Tennessee Valley Auth., 297 U.S. 288, 346-48 (1936) (Brandeis, J., concurring). Constitutional matters may be implicated in jurisdictional questions in any number of ways. The constitutionality of a jurisdictional statute may be in question, or alternatively, its interpretation may impinge on constitutional concerns. Distinct from the issue of subject matter jurisdiction, constitutional and statutory, are the jurisdictional questions deriving from the case or controversy requirement of article III, such as standing, ripeness, mootness, and administrative questions. Extra-statutory forms of jurisdiction such as ancillary and pendent jurisdiction must also conform to constitutional limitations.

107 Ashwander v. Tennessee Valley Auth., 297 U.S. 288, 345 (1936) (Brandeis, J., concurring) (quoting Adkins v. Children's Hosp., 261 U.S. 525, 544 (1923)). Applying the Ashwander doctrine to issues of subject matter jurisdiction works an extension of the principles enumerated by Justice Brandeis for dealing with the merits of cases "confessedly within" the Court's jurisdiction. Among the situations he noted, however, were several involving the case or controversy requirement, normally considered jurisdictional. Gunther, supra note 102, at 17. See also Rescue Army v. Municipal Court, 331 U.S. 549, 571 n.37 (1947). The Court has itself extended the doctrine to issues of subject matter jurisdiction. Neese v. Southern Ry., 350 U.S. 77 (1955); see Grunenthal v. Long Island R.R., 393 U.S. 156 (1968).

108 See generally $H$. Frmendey, Federal Jurisdiction: A Generax View (1973); 13 WrIGHT \& MIIrER, supra note 15, at $\$ 3510$.

109 Leventhal, Appellate Procedures: Design, Patchwork, and Managed Flexibility, 23 U.C.L.A. L. REv. 432 (1976).

110 Although the question apparently has never arisen, the value of promoting judicial economy would obviously require that judgments reached by means of hypothetical jurisdiction be considered res judicata.

In Stoll v. Gottlieb, 305 U.S. 165 (1938), the Court rested its finding that a jurisdictionally defective judgment was res judicata

on the fact that in an actual controversy the question of the jurisdiction over the subject matter was raised and determined adversely to the 
the resources necessary to decide them, are better allocated to cases in which the substantive issues do not render the jurisdictional issues merely theoretical.

A third policy, half jurisprudential and half administrative, looks not to the quantity of the judicial input, but to the quality of the product. The responsibility for the bulk of the basic decisionmaking concerning federal jurisdiction belongs, in the first instance, to Congress; however, statutory grants must be interpreted and the Constitution observed. In addition, the federal courts have traditionally exercised certain forms of extra-statutory jurisdiction, such as ancillary and pendent jurisdiction. ${ }^{111}$ If this shared responsibility to administer access to the federal judicial system is to be discharged effectively, then the courts, under the pressure of ever-growing dockets, must be allowed some flexibility in deciding when to decide complex jurisdictional issues. It is not beyond reason to suggest that clear and rational resolution of jurisdictional controversies has been hindered by the traditional requirement that they be adjudicated in every case in which they arise. ${ }^{112}$ Relief from this necessity may result in more thoughtful handling of jurisdictional problems, and thereby lead to a simplification of jurisdictional doctrines. ${ }^{113}$

respondent. That determination is res adjudicata of that issue in this action, whether or not power to deal with the particular subject matter was strictly or quasi-jurisdictional.

Id. 177. Chicot County Drainage Dist. v. Baxter State Bank, 308 U.S. 371 (1940), implicitly extended that doctrine to a jurisdictional issue the parties could have raised and had finally determined in the original proceeding, but did not. Id. 378. Both cases emphasize the actual or possible determination of the lower court in the original action. The question posed by hypothetical jurisdiction is whether a judgment can be res judicata when the jurisdictional issue was raised in the earlier proceeding but the court expressly chose not to decide it.

Clearly a determination that is never made cannot itself be res judicata, because nothing has been adjudicated. The jurisdictional issue bypassed by means of hypothetical jurisdiction is therefore not res judicata. But it does not follow from this that the judgment on the merits must fall to collateral attack.

The essential meaning of Stoll and Chicot County is that jurisdictional precepts should enjoy no "special sanctity." See note 50 supra. The same considerations of policy which affirm the practice by which federal courts avoid jurisdictional questions and decide on the merits should be applied in the context of collateral attack. Together with the additional strong interest in finality, these policy considerations surely outweigh any argument propounding the immortality of jurisdictional defects.

111 See text accompanying notes 74-89 supra.

112 See Bickel, supra note 102, at 47. Lack of adverseness may in some circumstances interfere with a court's ability properly to decide jurisdictional questions. See text accompanying note 104 supra. A factor commonly cited by courts as contributing to the decision to avoid the jurisdictional issues is inadequacy in the record, briefing, or argument. See, e.g., Secretary of the Navy v. Avrech, 418 U.S. 676, 677 (1974); Chandler v. Judicial Council, 398 U.S. 74, 88 (1970); Mitchell v. West Feliciana Parish School Bd., 507 F.2d 662, 666-67 (5th Cir. 1975).

113 The Supreme Court, of course, already enjoys wide discretion in deciding which cases to hear. In one hypothetical jurisdiction case, however, review was 
Apart from the quality of jurisdictional decisions, when made, it may sometimes be a valuable alternative not to find either jurisdiction or the lack of it, but to leave the issue undecided. ${ }^{114}$ When an appellate court is confronted with large issues such as expanding federal court review of court-martial convictions ${ }^{115}$ or the validity of pendent party jurisdiction, ${ }^{116}$ resolution of the jurisdictional questions may be too hasty and clumsy, whereas dismissal on the merits may send a more finely-tuned signal to the lower courts. Because it is responsible for regulating traffic in the federal judicial system, an appellate court may need to observe traffic conditions on a new avenue before responding to demands for particular signals.

Viewed functionally, federal jurisdiction represents the division of judicial labor as mandated by the Constitution and Congress and interpreted by the courts. ${ }^{117}$ The jurisdictional axiom that courts are powerless to act without jurisdiction over the subject matter is, as a general rule, essential to rational judicial management. However, when it appears that blind adherence to that rule or its various corollaries is wasteful or conflicts with important policies, sound principles of judicial administration require that it give way. Hypothetical jurisdiction, like res judicata, the bootstrap doctrine, and ancillary and pendent jurisdiction, can be another exception to the jurisdictional axiom that will promote the efficient and sensible management of the federal business of dispensing justice.

\section{Hypothetical Jurisdiction: Guidelines for Discretion}

In Part II, policy considerations were found to support the existence of judicial power to assume jurisdiction arguendo. Formulation of guidelines for the discretionary exercise of hypothetical jurisdiction can best be undertaken by reviewing the case law. Hypothetical jurisdiction can be viewed in terms of a continuum over which the justifiability of its use varies inversely with the difficulty and magnitude of the issues on the merits.

obligatory. Norton v. Mathews, 427 U.S. 524 (1976). The complexity of the jurisdictional issue or the unavailability of alternative grounds of decision may not appear until after review has been granted. Thus, in two cases the jurisdictional issue was the subject of the petition for writ of certiorari, but the Court dismissed on the merits. United States v. Augenblick, 393 U.S. 348, 351-52 (1969); Neese v. Southern Ry., 350 U.S. 77 (1955).

114 See Bickel, supra note 102, at 50-51.

115 See Secretary of the Navy v. Avrech, 418 U.S. 676 (1974); United States v. Augenblick, 393 U.S. 348 (1969).

116 See Moor v. County of Alameda, 411 U.S. 693 (1973).

117 See note 30 supra. 


\section{A. The Easy Case}

The easy hypothetical jurisdiction case is one in which the jurisdictional issues are weighty and complex, and favorable disposition of plaintiff's claims on the merits is foreclosed by sound precedent. That was the situation in Secretary of the Navy $v$. Avrech ${ }^{118}$ and Norton $v$. Mathews. ${ }^{119}$ In Avrech, the jurisdictional question concerned the power of a district court to review convictions of courts-martial in the context of a suit in which the relief sought was a declaratory judgment, back pay, and expunction of records. On the merits, the plaintiff argued that a provision of the military justice code was unconstitutionally vague, a contention that the Court had rejected in a case decided only a few weeks before. ${ }^{120}$

Norton v. Mathews came to the Court on appeal from the decision of a three-judge court upholding the constitutionality of a provision of the Social Security Act. ${ }^{121}$ In a companion case, ${ }^{122}$ the substantive issues had been decided against the plaintiff. The Norton Court affirmed the decision below, stating that the decision in the companion case rendered the substantive question "a decided issue and thus one no longer substantial in the jurisdictional sense." ${ }^{123}$ This was a reference to the much-questioned doctrine that federal courts have no jurisdiction over federal questions that are "frivolous" or "wholly insubstantial," 124 a criterion that is met if Supreme Court precedent is directly controlling. ${ }^{125}$

Although it might be argued that Norton and Avrech should be viewed not as turning on the merits, but rather as dismissing on an alternative jurisdictional ground, such an approach does little to further analysis of the phenomenon in question. The idea that dismissal for lack of a substantial federal question is a jurisdictional ruling rather than a decision on the merits is ill-conceived, and has

118418 U.S. 676 (1974).

110427 U.S. 524 (1976). See also Ellis v. Dyson, 421 U.S. 426 (1975); Franklin Savings Bank v. Levy, 551 F.2d 521, 527-28 (2d Cir. 1977); Smith v. Pennsylvania Unemployment Compensation Bd. of Review, 450 F. Supp. 1089 (E.D. Pa. 1978). Cf. McLucas v. DeChamplain, 421 U.S. 21, 32 (1975) (court did not reach issue of substantiality of claim, as plaintiff conceded that its insubstantiality required dismissal).

120 Parker v. Levy, 417 U.S. 733 (1974).

12142 U.S.C. $\$ \$ 402(\mathrm{~d})(3), 416(\mathrm{~h})(3)$ (c)(ii) (1976).

122 Mathews v. Lucas, 427 U.S. 495 (1976).

123 Id. 530-31.

124 Hagans v. Lavine, 415 U.S. 528 (1974); Bell v. Hood, 327 U.S. 678, 682-83 (1946).

125 Levering \& Garrigues Co. v. Morrin, 289 U.S. 103 (1933). 
been roundly criticized, even as it has been reiterated. ${ }^{126}$ Its continuing vitality as a doctrine appears to derive from its usefulness in the context of pendent jurisdiction, where it serves to discourage the use of frivolous federal claims as pretexts for bringing pendent claims into federal court. ${ }^{127}$

To exclude Avrech, Norton, and like cases from the sphere of hypothetical jurisdiction only undercuts understanding; these cases are better conceptualized as falling at the easy end of the hypothetical jurisdiction continuum. When the merits of a case cannot be considered due to identity with an unquestionably valid Supreme Court precedent, no purpose can be served by laboring over difficult jurisdictional questions. Not surprisingly, this "easy case" variety of hypothetical jurisdiction has enjoyed the widest use.

A closely related permutation has been employed in cases involving multiple parties and in consolidated cases in which jurisdiction is in question only as to one party but the merits are indistinguishable as to all. ${ }^{128}$ Rather than rule on the jurisdictional issue, the Court has found it convenient to dispose of such cases on the merits, on the ground that it was reaching the merits anyway with respect to the party or parties over whom jurisdiction was uncontested. In such cases, the particular procedural posture of the parties is unimportant; what matters is that the merits are identical and render the jurisdictional dissimilarity irrelevant.

\section{B. The Logical Limits of Hypothetical Jurisdiction}

In Philbrook $v$. Glodgett, ${ }^{129}$ an identity of substantive issues rendered the jurisdictional issue irrelevant, but the decision on the merits went in the plaintiffs' favor. If Glodgett is a hypothetical jurisdiction case, then hypothetical jurisdiction may be used not only to dismiss on the merits, but also to grant the requested relief. 130

The defendants in Glodgett-Vermont's commissioner of welfare and the Secretary of the United States Department of Health,

126 Hagans v. Lavine, 415 U.S. 528, 538 (1974); Rosado v. Wyman, 397 U.S. $397,404-05$ (1970).

127 See Bell v. Hood, 327 U.S. 678, 682 (1946).

128 Duke Power Co. v. Carolina Environmental Study Group, Inc., 438 U.S. 59, 72 n.16 (1978). See Southern Pac. Transp. Co. v. Usery, 539 F.2d 386, 389 n.1 (5th Cir.), cert. denied, 434 U.S. 874 (1976); Ripon Soc'y, Inc. v. National Republican Party, 525 F.2d 567, 574 (D.C. Cir. 1975), cert. denied, 424 U.S. 933 (1976).

129421 U.S. 707 (1975).

130 See text accompanying note 97 supra. 
Education, and Welfare-had agreed on a statutory interpretation that deprived the plaintiffs of welfare benefits to which they believed themselves entitled. A three-judge court found jurisdiction over the state commissioner under 28 U.S.C. $\$ 1343(3)$ and over the Secretary under principles of pendent party jurisdiction. ${ }^{131}$ The plaintiffs' interpretation of the statute was upheld; on appeal to the Supreme Court the Secretary contested the lower court's assertion of jurisdiction over him. Affirming on the merits, the Court dismissed the Secretary's jurisdictional appeal without deciding the complex question of pendent party jurisdiction. ${ }^{132}$

Less than a model of lucidity, the Court's reasoning on the jurisdictional question proceeded as follows: the Secretary, instead of complying with the Court's rules and adequately briefing the jurisdictional issue, had argued simply that the jurisdictional issue need not be decided-if the Court were to agree with the plaintiffs on the merits, he would comply voluntarily with its decision. ${ }^{133}$ Noting that failure to comply with its rules would ordinarily allow dismissal of the Secretary's appeal, the Court recognized that neither that rule nor the Secretary's "consent" to the Court's interpretation could dispose of the problem whether subject matter jurisdiction existed over the claim against the Secretary, a question that the Court, as a rule, is obliged to notice on its own motion, whether or not raised or waived by the parties. ${ }^{134}$ In this case, however, the Court found an exception to its duty to inquire into the jurisdiction of the district court: because the merits were indistinguishable as to both defendants and jurisdiction over the state commissioner was unquestioned, it would be necesssary for the Court to reach the merits anyway. Given the Secretary's willingness to cooperate and his failure properly to appeal in accordance with the Court's rules, the Court saw no harm in dismissing his appeal:

The exercise of the District Court's jurisdiction over the Secretary in this case, therefore, has resulted in no adjudication on the merits that could not have been just as properly made without the Secretary, and has resulted in no issuance of process against the Secretary which he has properly contended to be wrongful before this Court. ${ }^{135}$

131421 U.S. at 712,720 .

132 Id. $720-22$.

183 Id. 722.

134 See text accompanying note 17 stpra.

135421 U.S. at 722. 
The reference to "issuance of process" suggests that the Court's opinion turned on the ambiguity whether pendent party jurisdiction presents a question of jurisdiction over the subject matter or over the person. Ordinarily, when the pendent claim is not identical with the "federal" claim and is against the same party, there is no doubt but that jurisdiction over the pendent claim is classifiable as subject matter jurisdiction. But, the Court seemed to say, when the pendent claim is identical to the "federal" claim and impleads a new party, the jurisdictional question can be classified as one of jurisdiction over the person. As such, it may be waived, and the Court has no duty to decide it.

If this reading of the Court's opinion is accepted, then Philbrook $v$. Glodgett is not a hypothetical jurisdiction case because, in the final analysis, the jurisdictional issue was not of the sort that federal courts have a duty to resolve. ${ }^{136}$ A contrary interpretation would manifest an unexplained expansion of hypothetical jurisdiction. While all other hypothetical jurisdiction cases have been decided on the merits against the party asserting jurisdiction, Glodgett was decided in that party's favor. Such an interpretation would violate the logic of hypothetical jurisdiction, which may be stated as follows: in order for the plaintiff to recover, he must prove both (A) that the court has jurisdiction, and (B) that his claim is one

136 Two other cases which should not be confused with hypothetical jurisdiction are Schneckloth v. Bustamonte, 412 U.S. 218 (1973) and Regents of the Univ. of Cal. v. Bakke, 98 S. Ct. 2733 (1978). In Schneckloth, cited in Secretary of the Navy v. Avrech, 418 U.S. 676, 678 (1974), as support for arguendo assumption of jurisdiction, the state's argument that the exclusionary rule should not afford a basis for collateral attack in a habeas corpus proceeding was dismissed by the Court with the sentence: "Since we have found no valid Fourth and Fourteenth Amendment claim in this case, we do not consider that question." 412 U.S. at 249 n.38. However, the state's argument actually went to the merits of habeas corpus review, and was jurisdictional only in the exploded, old-fashioned sense in which courts had at one time discussed such review-in terms of procedural defects that had deprived the original trial court of "jurisdiction," thereby rendering the court's judgment void. See Amsterdam, Search, Seizure, and Section 2255, 112 U. PA. L. Rev. 378, 383 (1964). Thus in Stone v. Powell, 428 U.S. 465 (1976), in which the argument proposed by the state in Schneckloth eventually prevailed, the Court was careful to note that the jurisdiction of federal courts over habeas corpus petitions alleging fourth amendment violations was undisturbed by its ruling. Id. 494-95 n.37.

In Bakke, Justice Powell's opinion announcing the judgment of the Court assumed without deciding the existence of a private right of action under Title VI of the Civil Rights Act of 1964, 42 U.S.C. $\$ 2000$ d (1976). 98 S. Ct. at 2745. The bypassed issue went neither to the Court's subject matter jurisdiction nor to Bakke's standing, but only to the capacity of a private party to sue under Title VI. Unlike standing, capacity to sue is waivable. See Oklahoma v. Civil Service Comm'n, 330 U.S. 127, 134 (1947). Even Justice White, the only member of the Court to object to Justice Powell's assumption, seemed to believe that a decision on what he considered to be a "threshold jurisdictional issue" was not so much "obligatory" as it was "advisable." Id. 2794 (White, J.) (separate opinion). As a waivable requirement, capacity to sue, like personal jurisdiction, is not the sort of jurisdictional dictate with which hypothetical jurisdiction is concerned. 
deserving of relief on the merits. If either $A$ or $B$ is false, then the plaintiff must lose. Hypothetical jurisdiction, simply put, is the recognition that, logically, if $B$ is shown to be false, then the conjunction of $A$ and $B$ is necessarily false. The truth or falsity of $A$, in this case, becomes irrelevant.

Suppose, however, that B is true; that is, that the claim is one deserving of relief on the merits. Then the truth or falsity of $A$ must be determined: if $A$ is true (that is, if jurisdiction exists), the plaintiff wins; if false, he loses. To award relief without deciding the jurisdictional issue in this situation is to discard the jurisdictional requirement altogether; recovery would no longer be dependent on the truth of both $\mathrm{A}$ and $\mathrm{B}$, but on $\mathrm{B}$ alone. Hypothetical jurisdiction should not be confused with this latter situation. It is not used to erase jurisdictional requirements and grant otherwise unavailable relief. In a hypothetical jurisdiction case, jurisdiction is assumed for the purpose of argument and relief is denied on the merits. The requirement of jurisdiction is not discarded; it is still in force, only it need not be confronted because it can have no bearing on the ultimate disposition of the case.

It is this simple logic to which most courts appeal when they defend their assumption of jurisdiction by observing that the result will be the same however the jurisdictional knot is untied. ${ }^{137}$ This common sense "same result" approach, of course, ignores the traditional view of jurisdiction as a higher order affair, without which a court has no power whatever to reach the merits, whether ultimately decided for or against the plaintiff. ${ }^{138}$ Indeed, the "same result" approach proves too much, for it would generally allow courts to ignore jurisdictional requirements except when a decision in favor of the plaintiff was contemplated. By focusing solely on the effect on the parties, this approach ignores the important role that decisions, favorable and unfavorable, play in interpreting and declaring substantive law. Nevertheless, the logic of the "same result" approach does serve to mark the outer limits of hypothetical jurisdiction, which by definition can never be exercised unless the merits are against the party asserting jurisdiction.

\section{Cases of Intermediate Difficulty}

Between the easy case in which a finding on the merits in favor of the party asserting jurisdiction is foreclosed by precedent and

137 Slocum v. United States, 515 F.2d 237, 238 n.2 (5th Cir. 1975); Mitchell v. West Feliciana Parish School Bd., 507 F.2d 662, 667 (5th Cir. 1975); Finch v. Weinberger, 407 F. Supp. 34 (N.D. Ga. 1975).

138 See The Fair v. Kohler Die \& Specialty Co., 228 U.S. 22, 25 (1913). 
the outer limits bounded by the Glodgett result of deciding in that party's favor lies a broad range of cases utilizing hypothetical jurisdiction. Only slightly more difficult than the easy cases are those in which the jurisdictional issue is constitutional and the merits present the question whether the lower court abused its discretion. In Neese v. Southern Railway, ${ }^{139}$ in which only the jurisdictional question was presented by the petition for certiorari, the Court avoided the certified issue and upheld the lower court's use of discretion on the merits. The Court explicitly applied its policy of following "the traditional practice of this Court of refusing to decide constitutional questions when the record discloses other grounds of decision, whether or not they have been properly raised before us by the parties." ${ }^{140}$ Similarly, in Moor $v$. County of Alameda, ${ }^{141}$ the Court dodged the issue of the existence of article III power to assert pendent party jurisdiction over a county in an action brought under section 1983 of the Civil Rights Act of 1871,142 finding that, whether or not the lower court had such power, it acted within its discretion in dismissing the pendent claims. ${ }^{143}$

United States $v$. Augenblick, ${ }^{144}$ cited more frequently than any other case as authority for the application of hypothetical jurisdiction, cannot be assimilated to these easy and relatively easy cases. In separate proceedings, the Court of Claims had awarded back pay to two servicemen, finding their court-martial convictions constitutionally defective and hence invalid. The petitions for writs of certiorari were granted because of the importance of the jurisdictional question of the Court of Claims' power to review court-martial convictions for constitutional shortcomings in the context of backpay suits. ${ }^{145}$ Although the Court of Claims had long exercised that jurisdiction, the Government contended that changes in the applicable law had deprived the lower court of jurisdiction. On the merits, the respondents argued that various evidentiary irregularities at their courts-martial had deprived them of fair trials in violation of the Constitution.

139350 U.S. 77 (1955).

140 Id. 78 (citations omitted). See also Grunenthal v. Long Island R.R., 393 U.S. 156, 157-58 (1968), in which the Supreme Court bypassed a seventh amendment challenge to appellate jurisdiction to reach the merits of a tort claim.

141411 U.S. 693 (1973).

14242 U.S.C. $\$ 1983$ (1976).

143 Aldinger v. Howard, 427 U.S. 1 (1976), took up the question left open in Moor and held that pendent party jurisdiction had been impliedly negated by Congress in the circumstances of that case.

144393 U.S. 348 (1969).

145 Id. 349. 
In his opinion for a unanimous Court, Justice Douglas avoided the jurisdictional problem in a single sentence, concluding that "even if we assume, arguendo, that a collateral attack on a courtmartial judgment may be made in the Court of Claims through a back-pay suit alleging a 'constitutional' defect in the military decision, these present cases on their facts do not rise to that level." 146 Because Justice Douglas did not offer any justification for this procedure, the interpreter is necessarily left to his own devices to decipher it. ${ }^{147}$

On its face, Augenblick presented a jurisdictional problem of a statutory nature and merits of constitutional dimension, and was therefore an unlikely candidate for hypothetical jurisdiction. Lurking in the background of the jurisdictional challenge, however, were difficult and far-reaching constitutional issues concerning the proper relationship between "non-constitutional" courts-martial established pursuant to article I and "constitutional" article III courts. ${ }^{148}$ The magnitude of the jurisdictional problem appears even greater when one ponders the plausible, if speculative, notion that the issue in Augenblick may belong to that exclusive club of jurisdictional controversies capable of inflaming political sensibilities. Reaching the Court at the height of American military involvement in Vietnam, the issue of expanding civilian review of military justice may have been thought especially sensitive at a time when public opinion concerning the proper role of the military in civil society, and vice versa, was extremely volatile. Similar jurisdictional issues were dodged five years later in Secretary of the Navy $v$. Avrech; ${ }^{149}$ not until 1975, after the cessation of United States military activities in Southeast Asia, did the Court directly address these jurisdictional problems. ${ }^{150}$ From this perspective, the Court's repeated avoidance of the jurisdictional issue first raised in Augenblick was consistent

146 Id. 351-52.

147 Judge Adams of the Third Circuit, observing that "jurisdiction is a coat of many colors," has cited Augenblick as suggesting a malleable concept of jurisdiction. Brown v. United States, 508 F.2d 618, 630 n.5 (3d Cir. 1974) (Adams, J., concurring), cert. denied, 422 U.S. 1027 (1975). The problem here is to determine the limits of that plasticity.

148 Counsel for Augenblick asserted in their brief that if the Court were to find that the Court of Claims had in fact been deprived of its jurisdiction (a result they considered unlikely in light of the relevant legislative history), then the relevant provisions were unconstitutional. Brief for Respondent Augenblick, United States v. Augenblick, 393 U.S. 348 (1969), excerpted in 21 L. Ed. 2d 873-74 (1969).

149418 U.S. 676 (1974).

150 See Schlesinger v. Councilman, 420 U.S. 738, 745 (1975). 
with its steadfast refusal to open its doors to the voluminous litigation spawned by the Vietnam conflict. ${ }^{151}$

By comparison with the jurisdictional issues, the merits in Augenblick, although by no means determined by precedent as in Avrech or Norton, admitted of a facile resolution. Although the Court readily dismissed the claims as failing to allege defects of a constitutional nature, it nonetheless felt obliged to consider at some length the proper scope and import of the Jencks Act, ${ }^{152}$ and in the process offered some observations that are frequently cited as precedent by lower courts..$^{153}$

Unlike many other hypothetical jurisdiction cases, the decision in Augenblick appears not to have been influenced by any inadequacy in the record, briefs, or argument that might have hindered a judicious resolution of the jurisdictional question. On the contrary, the jurisdictional issue was the subject of the petition for certiorari and was fully argued. Nor can Augenblick be explained, as has been attempted, ${ }^{154}$ as a product of the policy of avoiding decision of constitutional issues, because both the jurisdictional and substantive contentions involved constitutional interpretation.

Although the Supreme Court has yet to articulate guidelines for the use of hypothetical jurisdiction that would elucidate the decisional principle in Augenblick, the Court of Appeals for the District of Columbia listed the requisite elements in Adams $v$. Vance. ${ }^{155}$ Drawing together Supreme Court precedents, Judge Leventhal announced in a footnote that

$[w]$ hen the merits of a case are clearly against the party seeking to invoke the court's jurisdiction, the jurisdictional question is especially difficult and far-reaching, and the inadequacies in the record or briefing make the case a poor vehicle for deciding the jurisdictional question, we may

151 See Sugarman, Judicial Decisions Concerning the Constitutionality of United States Military Activity in Indo-china: A Bibliography of Court Decisions, 13 Corum. J. Transnat'I L. 470 (1974).

15218 U.S.C. $\$ 3500$ (1976).

153393 U.S. at 354-56. See, e.g., United States v. Warme, 572 F.2d 57, 62 n.6 (2d Cir.), cert. denied, 435 U.S. 1011 (1978); Armstrong v. Collier, 536 F.2d 72, 77-78 (5th Cir. 1978); United States v. Bryant, 439 F.2d 642, 651-52 (D.C. Cir. 1971).

154 Weckstein, Federal Court Review of Courts-Martial Proceedings: A Delicate Balance of Individual Rights and Military Responsibilities, 54 Mr. L. REv. 1, 43-44 (1971); Note, Civilian Court Review of Court Martial Adjudications, 69 Colum. L. REv. 1259, 1271-72 (1969).

155570 F.2d 950 (D.C. Cir. 1978). In Adams, the court of appeals found it unnecessary to determine whether the request for relief involved a political question because the plaintiffs had failed to make the requisite "extraordinarily strong" showing on the merits. Id. 954-55. 
rule on the merits without reaching the inappropriately presented jurisdictional contention. ${ }^{156}$

The primary contribution of this formulation is the "clearly against" standard it applies to the merits. ${ }^{\mathbf{1 5 7}}$ That standard accurately describes the nature of the substantive issues posed in Augenblick as well as those in the cases discussed earlier. It fails, however, to account for cases that go further than Augenblick and employ hypothetical jurisdiction to decide cases on substantive merits that are difficult by any reasonable standard.

\section{The Hard Case}

Ripon Society, Inc. v. National Republican Party ${ }^{158}$ is a leading example of a case presenting difficult substantive, as well as jurisdictional, issues. The plaintiffs alleged that the formula for allocating delegates to the Republican National Convention denied them equal protection of the laws. This claim met with partial success in the district court and before a panel in the court of appeals. ${ }^{159}$ After a rehearing en banc, however, the court of appeals vacated the decision of the panel and entered judgment for the defendants. In addition to assuming political question justiciability, ${ }^{160}$ the court en banc assumed subject matter jurisdiction arguendo. Of ten judges participating in the decision, only five concurred in the court's opinion dismissing on the merits. Four concurred in the result, but would have dismissed on the jurisdictional questions; ${ }^{161}$ one dissented. If under these circumstances the merits may still be said to be "clearly against" the plaintiffs, then the term loses whatever usefulness it might have in determining which cases are appropriate for the use of hypothetical jurisdiction.

The defendants in Ripon Society argued that the lack of any state action deprived the court of jurisdiction under 28 U.S.G. $\$ 1343(3)$. Rejecting alternative bases of jurisdiction, the court assumed, without deciding, that state action was necessary to $\S 1343(3)$

156 Id. $954 \mathrm{n} .7$ (citations omitted).

157 By definition, every hypothetical jurisdiction case involves difficult and farreaching jurisdictional issues. The adequacy of the record and briefing, although often an element, is clearly not essential, as Augenblick demonstrates. (1976).

158525 F.2d 567 (D.C. Cir. 1975) (en banc), cert. denied, 424 U.S. 933

159 Ripon Soc'y, Inc. v. National Republican Party, 369 F. Supp. 368 (D.D.C. 1974), aff'd in part and rev'd in part, 525 F.2d 548 (D.C. Cir.), rev'd on rehearing en banc, 525 F.2d 567 (D.C. Cir. 1975), cert. denied, 424 U.S. 933 (1976). 160 See text accompanying notes 192-94 infra.

161 Of the four judges concurring in the result, two agreed with the majority opinion's views of the merits. 
jurisdiction and that state action was present in this case. ${ }^{162}$ If, as the court assumed, state action was necessary to the court's jurisdiction, then the jurisdictional question raised the constitutional problem whether a national political party, in apportioning delegates to its national convention, is subject to the strictures of the fourteenth amendment. ${ }^{163}$ Rather than tackle that weighty matter, the court preferred to confine itself to the narrower question, also of constitutional import, whether the procedure under attack was indeed violative of the equal protection clause.

Whether or not Ripon Society is acceptable as a legitimate exercise of hypothetical jurisdiction, it accurately demonstrates the appropriate test: hypothetical jurisdiction is justified when, on balance, the jurisdictional questions outweigh the substantive merits in difficulty and magnitude. This judicial inquiry manifests the balancing implicit in the Adams v. Vance formula. ${ }^{164}$

The closeness of the question in Ripon Society, demonstrated by the five-to-five split in the court of appeals, is an indication that the court was approaching the limits of its discretion to use hypothetical jurisdiction. The further a court is willing to stray from Judge Leventhal's "clearly against" standard, the more suspect the use of hypothetical jurisdiction becomes. When a court deals with momentous issues on the merits, such as the constitutional validity of the electoral process, the jurisdictional axiom acquires greater force, and assurances that the court is acting pursuant to jurisdictional authority become more desirable. The balancing analysis, although it accurately describes the judgment that must be made, is appropriate only within a limited range. Discretion to exercise hypothetical jurisdiction, decreasing in inverse proportion to the weightiness of the issues on the merits, at some indefinable point must cease to exist.

\section{E. Bypassing the Case or Controversy Requirement}

The bypassed issues in all of the preceding cases may be brought under the broad umbrella of subject matter jurisdiction. The Court

162525 F.2d at $576-77$ n.26.

163 The court of appeals had concluded in two analogous cases several years before that activities of the major parties constituted state action. See Bode v. National Democratic Party, 452 F.2d 1302 (D.C. Cir. 1971), cert. denied, 404 U.S. 1019 (1972); Georgia v. National Democratic Party, 447 F.2d 1271 (D.C. Cir.), cert. denied, 404 U.S. 858 (1971). Decisions of the Supreme Court in the interim, however, had cast doubt on the validity of these earlier cases. 525 F.2d at 596-98 (Tamm, J., concurring in the result). See Republican State Cent. Comm. v. Ripon Soc'y, Inc., 409 U.S. 1222 (1972); Brown v. O'Brien, 409 U.S. 1 (1972).

164 See text accompanying note 156 supra. 
has intimated, however, that the constitutional "case or controversy" requirement ${ }^{165}$ may also be avoided by a ruling on the merits.

Although not itself an example of hypothetical jurisdiction, Ellis v. Dyson ${ }^{166}$ suggests that federal courts may reach the merits of a case without resolving doubts about its justiciability. ${ }^{167}$ In that case, the plaintiffs sought a declaratory judgment that a local loitering ordinance was unconstitutionally vague. Without inquiring into the continuing existence of a controversy between the parties, the district court dismissed the complaint because, under controlling circuit precedent, federal courts were required to abstain. ${ }^{168}$ The court of appeals affirmed without opinion, and the Supreme Court reversed, based on its reversal in the interim of the circuit court precedent relied on by the district court. ${ }^{169}$

The Court implied that the lower courts had been correct to dismiss the claim without inquiring into its justiciability. Justice Powell, in dissent, argued that even under then-prevailing precedent the district court had been wrong to assume justiciability and dismiss on abstention grounds, labelling that procedure "a departure" from what he thought "to be the settled order of federal adjudication." 170 Justice Rehnquist, concurring, came to the Court's defense and explicitly argued in favor of the district court's assumption of justiciability, citing cases in which the Court had avoided questions of subject matter jurisdiction. ${ }^{171}$

165 "Case" and "controversy," Chief Justice Warren noted, are two words having "an iceberg quality, containing beneath their surface simplicity submerged complexities which go to the very heart of our constitutional form of government." Flast v. Cohen, 392 U.S. 83, 94 (1968). "Case or controversy requirement" refers to a collection of judicial doctrines interpreting the limits on federal judicial power imposed by article III, including the doctrines of standing, mootness, ripeness, administrative questions, and the rule against advisory opinions. See C. WragHT, LAW OF FEDERAL COURTS, $\$$ 12-15 (1976).

166421 U.S. 426 (1975).

167 "Justiciability" is here used to refer to the doctrines collected under the rubric of the case or controversy requirement and, in addition, the political question doctrine. See note 165 supra.

168358 F. Supp. 262 (N.D. Tex.), aff'd mem., 475 F.2d 1402 (5th Cir. 1973), rev'd, 421 U.S. 426 (1975).

169 The controlling case was Becker v. Thompson, 459 F.2d 919 (5th Cir. 1972), in which the Court of Appeals for the Fifth Circuit held that the principles of Younger v. Harris, 401 U.S. 37 (1971) applied to threatened as well as pending state criminal prosecutions. Becker was reversed in Steffel v. Thompson, 415 U.S. 452 (1974).

170421 U.S. at 450 (Powell, J., dissenting).

171 While it would have been more in keeping with conventional adjudication had ... . [the district] court first inquired as to the existence of a case or controversy, . . . I cannot fault the District Court for disposing of the case on what it quite properly regarded at that time as an authoritative ground of decision.

Id. 436 (Rehnquist, J., concurring). 
Neither the district court's nor the Supreme Court's opinion in Ellis $v$. Dyson is itself an example of hypothetical jurisdiction. The district court simply ignored the case or controversy problem; the Supreme Court, far from ignoring it, gave careful instructions that it be decided on remand. But the implication of the Court, made explicit by Justice Rehnquist, was that, as with subject matter jurisdiction, federal courts are free to bypass case or controversy conten. tions when dismissal on the merits is mandated by controlling precedent. ${ }^{172}$

Chandler $v$. Judicial Council ${ }^{173}$ is also authority for the proposition that a federal court may assume satisfaction of an article III case or controversy requirement, although in that case there is some confusion as to whether the Court actually ruled on the merits. ${ }^{174}$ Judge Chandler of the Western District of Oklahoma challenged the power of the Judicial Council of the Tenth Circuit to order assignment of cases and fix conditions on his exercise of judicial power. ${ }^{175}$ He sought from the Supreme Court a writ either of mandamus or of prohibition directed to the Council. The Judicial Council contended that its actions, purely administrative, had never been reviewed by a court, and that, under Marbury $v$. Madison, ${ }^{176}$ the desired writ lay outside the scope of the Court's original jurisdiction.

Surveying the difficulty of the substantive issues, the Court found it unnecessary to resolve them "because the threshold question in this case is whether we have jurisdiction to entertain the

172 Justice Rehnquist in Ellis, and the courts generally, have assumed that the same range of discretion should be enjoyed by the Supreme and lower courts alike in utilizing hypothetical jurisdiction. Considerations of judicial economy, however, justify allowing the range of discretion to increase with the degree of authority attaching to the court's judgment, so that it would not be impossible that hypothetical jurisdiction would be available to the Supreme Court yet denied to the district court when originally hearing the same case.

A decision by a district court is more likely to be reviewed on appeal than a decision of a court of appeals. When a lower court exercises hypothetical jurisdiction, the reviewing court will be deprived of the benefit of the lower court's consideration of the bypassed issue. If the reviewing court takes a different view of the merits or of the jurisdictional challenges, it may have no recourse but to remand on the jurisdictional issues, thus frustrating the savings in judicial energies envisioned by hypothetical jurisdiction.

These considerations will not come into play in the easy case, when the court is confident of being upheld on appeal. When the merits are more substantial, however, and the use of hypothetical jurisdiction is a close question, then the likelihood of review becomes another reason for confronting the jurisdictional questions. See text accompanying notes 163-66 supra.

173398 U.S. 74 (1970).

174 It is unclear whether the Court dismissed because the plaintiff had alternative recourse, see $i d$. $86-87$, or because the merits of the case were so insubstantial as to warrant dismissal, see $i d$. 88-89.

175 Id. 82.

1765 U.S. (I Cranch) 137 (1803). 
petition for extraordinary relief." 177 But the question of jurisdiction to review required a determination whether the actions of the Judicial Council were judicial or administrative in nature, a question going to the "constitutional requirement that such review be appellate." 178 The Court also declined to answer that question, concluding that "in the present posture of the case other avenues of relief on the merits may yet be open to Judge Chandler." 179

This conclusion resembles the rule of equity that refuses equitable relief when the plaintiff has adequate remedies at law. Traditionally, such lack of equity jurisdiction was viewed in terms of the court's power, ${ }^{180}$ but the modern approach treats dismissal for lack of equity jurisdiction as a decision on the merits. ${ }^{181}$ That appears to have been the view of Justice Harlan who, concurring in the Chandler judgment, criticized the Court for not first determining its jurisdiction..$^{182}$ Chandler, so interpreted, stands for the proposition that federal courts may skip over article III case or controversy questions to dismiss for want of equity..$^{183}$

Although there is thus no Supreme Court opinion unequivocally holding that it is permissible to assume justiciability and rule on the substantive merits, the Court of Appeals for the District of Columbia has so held on several occasions. Standing, ${ }^{184}$ ripe-

177398 U.S. at 86.

178 Id.

$179 I d$.

$180 \mathrm{Z}$. Ceaffes, supra note 46, at 304 .

181 Di Giovanni v. Camden Fire Ins. Ass'n, 296 U.S. 64, 69 (1935); Z. CHAFEe, supra note 46 , at $296-363$.

Chief Justice Burger suggested that the merits of Judge Chandler's action were deficient when he stated that "plainly petitioner has not made a case for the extraordinary relief of mandamus or prohibition." Chandler v. Judicial Council, 398 U.S. 74, 89 (1970).

182398 U.S. at 91-93 (Harlan, J., concurring in the judgment).

$183 \mathrm{An}$ analogous procedure was employed in United States v. A.T.\&T., 551 F.2d 384 (D.C. Cir. 1976). Judge Leventhal, writing for the court, bypassed a political question issue and, without reaching the merits, remanded with suggestions for negotiations between the parties to be monitored by the district court. See generally Comment, United States v. AT\&T: Judicially Supervised Negotiations and Political Questions, 77 Colum. L. REv. 466 (1977). The parties remained somewhat intransigent, and on their second trip to the court of appeals, the political question issue was decided. 567 F.2d 121 (D.C. Cir. 1977). The case is only superficially an instance of hypothetical jurisdiction: consideration of political question justiciability was merely postponed, not assumed.

184 Edwards v. Carter, 580 F.2d 1055 (D.C. Cir.), cert. denied, 436 U.S. 907 (1978); Chinese Am. Civic Council v. Attorney Gen., 566 F.2d 321 (D.C. Cir. 1977); Ripon Soc'y, Inc. v. National Republican Party, 525 F.2d 567 (D.C. Cir. 1975), cert. denied, 424 U.S. 933 (1976). 
ness, ${ }^{185}$ non-mootness, ${ }^{186}$ and political question justiciability ${ }^{187}$ have all been assumed arguendo, and the cases disposed of on the merits. For the most part these instances of hypothetical jurisdiction are unexceptional, and no reason appears for treating justiciability issues differently from questions of subject matter jurisdiction. Indeed, the fact that these separate doctrines are partly constitutional in origin and partly of a prudential nature, ${ }^{188}$ admitting of discretion in their application, might be taken to render them better suited than subject matter issues to be bypassed by means of hypothetical jurisdiction.

The use of hypothetical jurisdiction to avoid political question contentions must, however, be closely scrutinized. Unlike standing, ripeness, or mootness, which focus on the plaintiff or the case in a specific factual context, the political question doctrine attaches directly to the issues on the merits. ${ }^{189}$ Roughly speaking, the central notion of the doctrine is that there exist certain questions that cannot be judicially resolved, either because they have been textually committed by the Constitution to a coordinate branch of government or because various prudential considerations, arising from the separation of powers and the inherent limitations of the judicial process, render those questions unfit for judicial determination. ${ }^{190}$

When a court assumes arguendo the nonexistence of a political question and decides a case on its merits, a logical conflict is created. The issue purportedly reserved-whether the controversy on the merits is a proper subject for judicial resolution-has in fact been decided in the affirmative. The very act of decision implies that the merits can be and have been resolved judicially. Hypothetical jurisdiction with respect to political questions is therefore logically barred, because deciding the issue on the merits necessarily implies a decision that no political question exists. ${ }^{191}$

185 Edwards v. Carter, 580 F.2d 1055 (D.C. Cir.), cert. denied, 436 U.S. 907 (1978); Clark v. Valeo, 559 F.2d 642 (1977) (Leventhal, J., concurring).

186 Pickus v. United States Bd. of Parole, 543 F.2d 240 (D.C. Cir. 1976).

187 Edwards v. Carter, 580 F.2d 1055 (D.C. Cir.), cert. denied, 436 U.S. 907 (1978); Adams v. Vance, 570 F.2d 950 (D.C. Cir. 1978); Ripon Soc'y, Inc. v. National Republican Party, 525 F.2d 567 (D.C. Cir. 1975), cert. denied, 424 U.S. 933 (1976).

188 Flast v. Cohen, 392 U.S. 83,97 (1968).

189 See Scharpf, supra note 23 , at 537-39.

190 Baker v. Carr, 369 U.S. 186, 217 (1962). One of those prudential considerations, the notion that a court cannot decide a case when there are no judicially manageable standards to guide its decision, is frequently considered to be a third strand of political question analysis. See Coleman v. Miller, 307 U.S. 433 (1939); G. Gunther, Cases and Materials on Constitutional Law 1617-22 (1975). 191 Justices Harlan and Stewart expressed a similar skepticism at the Court's use of hypothetical jurisdiction in Grunenthal v. Long Island R.R., 393 U.S. 156 (1968). 
This result is demonstrated by Ripon Society, Inc. v. National Republican Party. ${ }^{192}$ Confronted with the defendant's objection that the merits of the case posed a political question, the court assumed justiciability without deciding it and denied relief on the merits, perceiving no offense against the equal protection clause of the fourteenth amendment. In the court's view, finding a political question would have required "the more drastic step of holding that we would never be competent to reach a contrary conclusion." 193 This language implies that, at least in that case, the court thought itself competent to render a decision and that consequently no nonjusticiable political question was at stake..$^{194}$

The approach in Ripon Society is ultimately indistinguishable from cases in which the Supreme Court, although recognizing the force of the political question argument, has nevertheless found

There the bypassed issue was one of subject matter jurisdiction-whether the seventh amendment prohibited appellate review of a district court's refusal to set aside a verdict for excessiveness. While Justice Harlan stopped at expressing his inability to understand the Court's "legal gymnastics," id. 163 (Harlan, J., dissenting), Justice Stewart went on to state that by proceeding to the merits the Court had necessarily decided the jurisdictional point. Id. 164 (Stewart, J., dissenting).

Although the practical effect of the Court's avoidance guaranteed as effectively as any decision that appellate review of such trial court rulings would continue unabated, as a matter of analysis, this Comment must take issue with Justice Stewart's position. To say that reaching the merits necessarily implies a finding of subject matter jurisdiction, despite an express disclaimer, is to subscribe in full to the jurisdictional axiom and the notion that jurisdiction is a logically necessary condition of deciding a case on the merits. Modern developments in jurisdictional practice have significantly eroded that view and dispelled its fascination with a logico-mathematical approach to jurisdictional concepts. See Parts I \& II supra.

In this regard, subject matter jurisdiction and the case or controversy requirement must be distinguished from the political question doctrine. No logical necessity binds the former to the determination of the merits of a case. But the unique nature of the political question inquiry, which looks to the issues on the merits, is such that adjudication of the merits of the controversy logically implies a finding that no non-justiciable political question exists. Hence the logical difficulty in using hypothetical jurisdiction to avoid political question objections is inescapable.

It has been argued that standing decisions can best be understood as in fact disposing of cases on their merits. Albert, Standing to Challenge Administrative Action: An Inadequate Surrogate for Claim for Relief, 83 YALE L.J. 425 (1974). To the extent that this is true, courts that purport to assume standing without deciding it must also be seen as merely going through the motions of hypothetical jurisdiction.

192525 F.2d 567 (D.C. Cir. 1975), cert. denied, 424 U.S. 933 (1976). See text accompanying notes 158-63 supra.

$193525 \mathrm{~F} .2 \mathrm{~d}$ at 578 (footnote omitted).

194 Professor Wright's comment on this procedure, as ambivalent as is the court's, suggests the same result: "The objection that political questions are nonjusticiable, and accordingly should be dismissed without determination of the merits, is no stronger than the underlying conviction that at least questions at the core of the possibly nonjusticiable area can presently be answered." 13 WRIGHT \& MIrLER, supra note 15, \$3534, at 174 (Supp. 1978). 
room for limited judicial review. ${ }^{195}$ This cautious approach, although perhaps bearing some resemblance to hypothetical jurisdiction, represents nothing more than a carefully limited finding of justiciability that reserves judgment on other cases and situations not presented. By contrast, use of hypothetical jurisdiction does not resolve the jurisdictional issue, but disposes of the case on the merits, which are separate and distinct. Because of the peculiar nature of political question justiciability, hypothetical jurisdiction cannot meaningfully be used with respect to it. It can only engender confusion to purport to invoke hypothetical jurisdiction in that context, as the Court of Appeals for the District of Columbia has repeatedly done..$^{196}$

\section{F. Summary}

It is clear, if only from the relative scarcity of cases, that use of hypothetical jurisdiction is not favored by the courts. In the overwhelming majority of cases, the jurisdictional axiom still prevails and jurisdictional problems must be resolved before reaching the merits. Judicial power to exercise hypothetical jurisdiction exists only when a case poses a jurisdictional question that is difficult and far-reaching. The logic of hypothetical jurisdiction requires that it be available only when the merits are decided against the party seeking to invoke the court's jurisdiction. Given these two prerequisites, judicial discretion to exercise hypothetical jurisdiction involves a balancing test that weighs the relative difficulty and magnitude of the jurisdictional questions against the substantive issues. The strongest case for its use occurs when dismissal on the merits is clearly required by valid precedent. Even when the merits are not thus "insubstantial," hypothetical jurisdiction is possible when the merits are clearly against the party asserting jurisdiction. Although it is within a court's discretion to exercise hypothetical jurisdiction when the merits are not so easily resolved provided that the balancing test is satisfied, caution must be observed as the merits increase in magnitude and complexity. At some point, the utility of hypothetical jurisdiction vanishes and the limits of discretion are transgressed.

One factor that, although not essential, is often present and may serve to tip the balance in favor of hypothetical jurisdiction, is

195 Fiallo v. Bell, 430 U.S. 787, 792 (1977). Accord, Mathews v. Diaz, 426 U.S. $67,81-82$ (1976).

196 See Edwards v. Carter, 580 F.2d 1055 (D.C. Cir.), cert. denied, 436 U.S. 907 (1978); Adams v. Vance, 570 F.2d 950 (D.C. Cir. 1978); Ripon Soc'y, Inc. v. National Republican Party, 525 F.2d 567 (D.C. Cir. 1975), cert. denied, 424 U.S. 933 (1976). 
inadequacy in the record, briefing, or argument, which makes the case a poor vehicle for dealing with weighty jurisdictional problems.

Except for issues of political question non-justiciability, case or controversy questions, like subject matter jurisdiction, are amenable to hypothetical jurisdiction.

\section{Edwards v. Carter RECONSWERED}

The potential for abuse inherent in hypothetical jurisdiction is nowhere more strikingly illustrated than in the court of appeals' decision in Edwards $v$. Carter ${ }^{197}$ Faced with complex jurisdictional challenges to standing, ripeness, and the existence of a non-justiciable political question, ${ }^{198}$ a strongly divided court ignored the threshold questions and proceeded to dismiss on the merits.

The court's attempt to bring itself under the rule enunciated in Adams $v$. Vance ${ }^{199}$ by characterizing the merits as "so clearly against the parties asserting jurisdiction" 200 was somewhat disingenuous, as its own opinion demonstrates. Although it had been a topic of concern at the Constitutional Convention and among the ratifying states, ${ }^{201}$ the use of the treaty power to dispose of federal property had never before been the subject of a constitutional holding. ${ }^{202}$ It had been viewed in various ways by esteemed constitutional scholars, ${ }^{203}$ and examination of Supreme Court precedent ${ }^{204}$ and past practice yielded no uniform approach. ${ }^{205}$ Judge MacKinnon's thorough and ardent dissent, if not ultimately convincing, left no doubt that the substantive issues were by no means "clearly against" either party. ${ }^{206}$

Justification for the court's procedure of assuming jurisdiction arguendo, although not forthcoming from the Adams v. Vance standard, might nevertheless be achieved if the balancing analysis were to show that the magnitude and difficulty of the jurisdictional

197580 F.2d 1055 (D.C. Cir.), cert. denied, 436 U.S. 907 (1978).

198 See text accompanying notes 1-8 supra.

199570 F.2d 950, 954 n.7 (D.C. Cir. 1978); see text accompanying note 156 supra.

200580 F.2d at 1057.

201 Id. 1059-61.

202 Id. 1061.

203 Id. 1057 n.4.

204 Id. 1061-63.

205 Id. 1063.

206 Id. 1064 (MacKinnon, J., dissenting). 
questions were relatively greater than the constitutional issue on the merits. At the outset, the fact of multiple jurisdictional issues suggests caution. Even if one or two of these were of great complexity or far-reaching, dismissal might still have been predicated on the third, making it unnecessary to decide the others. Only if each jurisdictional issue, standing alone, either outweighed the gravity of the issue on the merits or posed no obstacle to jurisdiction, would the balancing test have been satisfied. ${ }^{207}$ Moreover, even if all three jurisdictional questions passed that test, if any one provided a nonconstitutional ground of dismissal, then the policy of avoiding constitutional adjudication unless absolutely necessary would have dictated dismissing the case for lack of jurisdiction. Given the largely prudential makeup of the standing, ripeness, and political question doctrines, this hurdle to the exercise of hypothetical jurisdiction assumes large proportions.

It is doubtful that the threshold questions in Edwards $v$. Carter were so novel or difficult as to justify the use of hypothetical jurisdiction. The court of appeals had addressed the issue of legislator standing on several prior occasions, in cases in which the merits were of no greater import than the issue of the scope of the treaty power. $^{208}$ On this issue alone the court could have dismissed the action by adopting the opinion below. The ripeness problem posed in $E d w a r d s$, although perhaps a close call, revealed no special doctrinal difficulties that would create pressure for avoidance. ${ }^{209}$ No

207 By comparison, in Ripon Soc'y, Inc. v. National Republican Party, 525 F.2d 567 (D.C. Cir. 1975), cert. denied, 424 U.S. 933 (1976), a "hard" hypothetical jurisdiction case, the court at least felt obliged to decide the standing issue with respect to several of the plaintiffs, observing that "[w]e would not wish to rule one way or the other in this case without satisfying ourselves that that [standing] requirement had been met." Id. 571 (footnote omitted).

208 Harrington v. Bush, 553 F.2d 190 (D.C. Cir. 1977); Metcalf v. National Petroleum Council, 553 F.2d 176 (D.C. Cir. 1977); Kennedy v. Sampson, 511 F.2d 430 (D.C. Cir. 1974); Mitchell v. Laird, 488 F.2d 611 (D.C. Cir. 1973); Public Citizen v. Sampson, 379 F. Supp. 662 (D.D.C. 1974), aff'd mem., 515 F.2d 1018 (D.C. Cir. 1975). Since Edwards, another congressional standing case has been decided. Reuss v. Balles, 584 F.2d 461 (D.C. Cir. 1978). See generally Note, Congressional Access to the Federal Courts, 90 Harv. L. Rev. 1632 (1977).

209 Counsel for the President contended that the case was premature because the Senate had not yet given its consent to the treaty. The district court found the lack of ripeness a factor in rendering the injury to the plaintiffs too abstract and speculative to confer standing. Pointing to the possibilities that the House could approve a property transfer, that the Senate could enact treaty amendments, reject the treaty, or adopt amendments unacceptable to Panama, and that diplomatic complications could arise before or after ratification, the district court noted:

Postulating that these events will not come to pass, plaintiffs deny that a judicial opinion will be only advisory at this point in time. The Court is not prepared to second-guess the political contingencies inherent in the treaty making and legislative processes. Nor can the Court now assess 
reason appears why the political question challenge was necessarily of greater scope than the constitutional issue actually decided by the court.210 The issue whether the President's making of a treaty is immune from judicial review while the treaty-making process is still going on is arguably narrower in scope and less difficult than the issue of the proper extent of the treaty power relative to the disposal power of Congress. ${ }^{211}$ Nor was there any inadequacy in the record or briefing, as the jurisdictional issues were fully litigated in the district court and the court of appeals.

That a balancing of the issues posed by Edwards $v$. Carter fails to justify the court's wholesale exercise of hypothetical jurisdiction is an almost inescapable conclusion. This criticism is supported by the court's own brief discussion of its procedure, which manifests an eagerness to reach the merits, fueled by considerations apart from the subtlety and far reach of the threshold issues.212 The court's

plaintiffs' contention that ratification means a fait accompli, protected from judicial interference.

Edwards v. Carter, 445 F. Supp. 1279, 1286 (D.D.C.), affd, 580 F.2d 1055 (D.C. Cir.), cert. denied, 436 U.S. 907 (1978).

For the view that standing probably should have been granted, but that the court of appeals should have dismissed the case on ripeness grounds, see Case Comment, Transfer of the Panama Canal by Treaty Without House Approval: Edwards v. Carter, 92 Harv. L. REv. 524, 529-31 (1978).

210 See text accompanying notes 189-96 supra.

211 The representatives sought, in effect, a declaratory judgment that the President had gone about making the treaty in an unconstitutional manner. Although the courts are often called upon to interpret treaties once made, it is another thing entirely to engage in pronouncements on the constitutional soundness of a treaty still in the formation process. That function, it can be argued, is committed by article II, section 2, clause 2 of the Constitution to the Senate, in its advice and consent capacity.

In addition to this textual commitment element, various prudential considerations arguably rendered the case non-justiciable. For example, a court judgment in favor of the plaintiffs might have created an embarrassing situation for the President and destroyed a delicate diplomatic balance. If the disposal power were held to be exclusive, as the representatives urged, and the property transfer to require a vote by the full Congress, there would remain the question whether the House was entitled to vote before the Senate, simultaneously with the Senate, or only after the treaty was ratified. Might the President merely present legislation implementing other aspects of the treaty, on the theory that congressional approval of the property transfer could be inferred from passage of the overall package? These questions of the timing of submission of a treaty to the Senate and implementing legislation to Congress are political judgments that require a delicate sensitivity to national and international complications, and that lack judicially discoverable or manageable standards. See Baker v. Carr, 369 U.S. 186, 217 (1962). However these contentions might have been resolved, they were not of the sort that should be bypassed by means of hypothetical jurisdiction. See text accompanying notes 189-91 supra.

212 In addition to its argument on the merits, appellee has presented several substantial and complex challenges to the jurisdiction of the federal courts to adjudicate the merits of the constitutional question presented in this case. We refer not only to the contentions as to lack of standing, but also to the arguments that appellants' action is both premature and 
stated concern over the possibility of a remand and further lengthy proceedings and the allusion to "time constraints imposed by the immediacy of Senate action on the treaties" ${ }^{213}$ indicate a desire to put an authoritative end to the litigation before the treaty came to a vote in the Senate, and to disperse the cloud of constitutional doubt overhanging the President's choice of the treaty-making procedure. ${ }^{214}$

Depending on one's jurisprudential ideology, such concern with the public or political interest of a case either smacks of the worst sort of judicial politicking or embodies the highest form of judicial statesmanship. Here there is no need to choose sides, for this Comment is not concerned with the result in Edwards v. Carter, nor with the fact that the court reached the constitutional question. The problem lies solely in the use of hypothetical jurisdiction to proceed to resolution of the merits.

Judicial authority depends "altogether on the force of the reasoning by which it is supported." 215 To decide the grave matters presented by $E d w a r d s$ without a clear showing of necessity can only lead to disrespect for the judicial process. Thus the utility of hypo-

presents a nonjusticiable political question. Deciding only the jurisdictional issue before us could result in this court, or the Supreme Court, remanding the case for further proceedings either on the merits or on jurisdictional issues. Because the merits of this controversy present a pure question of law, with no need of a hearing for fact development, because these merits are so clearly against the parties asserting jurisdiction, and because the judgment appealed from was based on only one of several asserted grounds of lack of jurisdiction, we believe it is appropriate to proceed directly to the merits of this case. This conclusion is bolstered when the time constraints imposed by the immediacy of Senate action on the treaties are considered.

Edwards v. Carter, 580 F.2d 1055, 1056-57 (D.C. Cir.), cert. denied, 436 U.S. 907 (1978).

213 Id. 1057. Had the court decided in favor of Representative Edwards, its concern over prospective Senate action would have been understandable. But given that the complaint was to be dismissed, it is difficult to comprehend the necessity for haste, unless the court was worried lest the Senate vote without benefit of its advice. Furthermore, the inevitable petition for review by the Supreme Court ensured that the court of appeals' determination would not finally dispose of the case. In fact, the Senate consented to the treaty on April 18, 1978, 124 Cong. REc. S5796 (daily ed. Apr. 18, 1978), and the Supreme Court did not deny certiorari until a month later, on May 15, 1978. 436 U.S. 907 (1978).

$214 \mathrm{~A}$ number of prior attempts to obstruct the progress of the Panama Canal Treaties had failed. Idaho v. Vance, 434 U.S. 1031 (1978); McClure v. Linowitz, No. 77-436 (D.D.C. May 11, 1977); Helms v. Vance, No. 77-83 (D.D.C. Mar. 23, 1977), aff'd, No. 77-1295 (D.C. Cir. May 3, 1977), cert. denied, 432 U.S. 907 (1977); Drummond v. Bunker, No. 76-0353-B (D.C.Z. Jan. I1, 1977), affd, 560 F.2d 625 (5th Cir. 1977). In the most recent effort, decided after Edwards, the plaintiffs were found to lack standing. Mease v. Heinz, 80 F.R.D. 119 (E.D. Pa. 1978).

215 Wechsler, supra note 102, at 17 (quoting the Passenger Cases, 48 U.S. (7 How.) 283, 470 (1849) (Taney, C.J., dissenting)). 
thetical jurisdiction is at its maximum when the substantive issues are of small stature. ${ }^{216}$ When, as in Edwards $v$. Carter, the public interest is intense, exercise of hypothetical jurisdiction fosters legitimate fears of "free wheeling interventionism" and judicial expediency. ${ }^{217}$

\section{Conalusion}

Hypothetical jurisdiction-the practice of assuming jurisdiction arguendo and disposing of a case on the merits-has developed in federal courts as an intuitive and practical exception to the rule that questions concerning the court's jurisdiction may be raised and must be noticed at any time prior to final judgment or on appeal. This Comment has explored the policies underlying use of hypothetical jurisdiction and has distilled limits on its use from a survey of the cases.

The exception that hypothetical jurisdiction carves out of the jurisdictional axiom is presaged by and analogous to inroads made by res judicata, the bootstrap doctrine, the modern expansion of ancillary and pendent jurisdiction, and proposals to foreclose objections to subject matter jurisdiction prior to final judgment. In each of these areas, principles of sound judicial administration require a more malleable concept of jurisdiction and its relationship to judicial power than the traditional dogma permits.

Hypothetical jurisdiction stems from the general policy of avoiding constitutional adjudication unless necessary to the disposition of a case. It conserves increasingly limited judicial resources and fosters thoughtful and principled handling of important jurisdictional questions.

Hypothetical jurisdiction may be used only when the jurisdictional questions are difficult and of great consequence and the substantive merits are adverse to the party asserting jurisdiction. Once these two prerequisites are satisfied, the decision to exercise hypothetical jurisdiction depends upon whether the threshold jurisdictional issues outweigh the merits in magnitude and complexity. If consideration of the substantive issues has been foreclosed by controlling Supreme Court precedent or if the merits are clearly against the party invoking the court's jurisdiction, then exercise of hypothetical jurisdiction is well within the court's discretion. As the substantive issues increase in weight and difficulty, so does concern

216 See text accompanying notes 163-66 supra.

217 See Gunther, supra note 102, at 25. 
over possible lack of jurisdiction; as a result, hypothetical jurisdiction concomitantly becomes less legitimate.

Case or controversy issues, as well as subject matter jurisdiction, may also be bypassed by means of hypothetical jurisdiction, with the exception that the political question doctrine cannot meaningfully be avoided by an assumption for the purpose of argument.

A narrow exception to traditional canons, hypothetical jurisdiction contains great potential for abuse. When the substantive issues are of great import, the temptation to decide them may be strong, and glib abuse of the hypothetical jurisdiction technique can satisfy that urge. Thus may the limits on federal court jurisdiction imposed by the Constitution and Congress be finessed by means of a logical device.

Edwards $v$. Carter ${ }^{218}$ amply demonstrates that concern over the abuse of hypothetical jurisdiction is not idle speculation. In that case, the Court of Appeals for the District of Columbia passed over issues of standing, ripeness, and the existence of a non-justiciable political question to decide a grave and novel constitutional issue on its merits. Whatever the court's reasons for reaching the merits, its use of hypothetical jurisdiction to do so is not likely to increase respect for the judicial process.

Hypothetical jurisdiction provides a useful technique for improving the quality and efficiency of judicial administration. Properly used, it can promote the development of sound jurisdictional doctrine. If, however, the limits on its exercise are not observed, hypothetical jurisdiction can be used to assume restrictions on federal judicial power out of existence, and thereby to unravel the constitutional fabric, stitch by stitch. 